\title{
B2 Integrin Antagonism, A Potential Mechanism To Sensitize CML Cells To Therapy As Revealed From Genetic Response To Radiation And LiCl
}

\section{Yogesh Kumar Verma}

Institute of Nuclear Medicine \& Allied Sciences

Namrata Yadav

Institute of Nuclear Medicine \& Allied Sciences

Subodh Kumar

Institute of Nuclear Medicine \& Allied Sciences

Gangenahalli Ugraiah Gurudutta ( $\sim$ gangenahalligurudutta@gmail.com )

Institute of Nuclear Medicine \& Allied Sciences

\section{Research Article}

Keywords: Cell survival, microarray data analysis, cell adhesion molecules, integrins, migration

Posted Date: September 29th, 2021

DOl: https://doi.org/10.21203/rs.3.rs-885452/v1

License: (c) (i) This work is licensed under a Creative Commons Attribution 4.0 International License. Read Full License 


\section{Abstract}

Background: The interaction of integrins and growth factor receptors in cells is tightly regulated, ensuring cell survival, proliferation, differentiation, adhesion, and migration. The IR generates reactive oxygen species, which leads to ECM remodeling and cell adhesion through the activation of proteases, soluble cytokines and growth factors. Integrins and adhesion of cells to ECM confer higher resistance to ionizing radiation and cytotoxic drug, a phenomenon known as cell adhesion mediated radiation resistance (CAM$\mathrm{RR}$ ) and cell adhesion mediated drug resistance (CAM-DR). Integrins' involvement in CML progression is well appreciated through its survival, adhesion and migration signaling. The evaluation of global genetic response (in microarray) of ionizing radiation (IR) on integrins expression has not been attempted to specify theirrole and other cell adhesion molecules (CAMs) in CML. In this study, we have compared the microarray based CAMs response in myelogenous leukemia cells onIR exposure.

Results: Results revealed differential regulation of many CAMs, with strongest expression of integrin $\beta 2$ (CD18), whose role has not been fully appreciated in CML due to low level of expression. However, the synergistic LiCl(GSK3 $\beta$ inhibitor) and IR treatment significantly upregulates CD18 expression leading to enhanced survival, cell adhesion mediated drug/radiation resistance (CAM-DR/RR) and transcription of migration related genes. These effects could be undermined in the presence of CD18 antibody. This may be one of the reasons for $\mathrm{CML}$ resistance to radiation therapy and its relapse upon stem cell transplantation.

Conclusion: This study proposes CD18 antagonist administration as an adjuvant in anti-CML therapy and other cancers in which it displays aberrant expression subsuming the contraindication of GSK3 $\beta$ inhibitor. Nevertheless, the CD18 mediated cell adhesion in tumor progression beckons development of improved drug regimensandidentification of diagnostic and prognostic signature for CML.

\section{Introduction}

Chronic Myelogenous Leukemia (CML) mainly occurs in adults due to single genetic anomaly; a reciprocal chromosomal translocation between the C-ABL (Abelson leukemia virus) oncogene on chromosome 9 and the BCR (breakpoint cluster region) on chromosome 22. The resulting BCR/ABL gene encodes a fusion tyrosine kinase, which causes deregulation in cell cycle, apoptosis, differentiation and DNA repair. It differs from acute myelogenous leukemia (AML) in slow growth and presents with symptoms, which are not readily recognized as extreme. Treatment options for CML include targeted therapy with tyrosine kinase inhibitors (TKI), interferon, radiotherapy, and stem cell transplant (1). CML cells express integrins VLA-4 and VLA-5, and display cell adhesion mediated drug/radiation resistance (CAM-DR/RR) when exposed to BCR/ABL inhibitors, DNA damaging drugs and ionizing radiation(IR) (2). Through production of reactive oxygen species, IR leads to extra cellular matrix (ECM) remodeling and cell adhesion by activation of integrins, which are the main receptors for ECM protein like fibronectin(3). 
The integrin family's cell adhesion molecules (CAMs) are made up of 18 and 8 subunits that form 24 known -heterodimers. Integrins are the main receptors for ECM proteins like collagen, fibronectin, and laminin. In cells, the cell matrix interaction via integrin are necessary for embryonic development, proliferation, survival, adhesion, differentiation, and cell migration, among other things (4-5). K652 cells adherence to fibronectin is mediated by a $5 \beta 1$ integrin, leads to apoptosis resistance after treatment with the BCR/ABL inhibitors AG957 and STI-571 as well as DNA damaging drugs and $y$-radiation (6). Induction of apoptosis in fludarabine-, etoposide-, or bleomycin-treated human leukaemia cells was shown to be prevented by integrin-mediated adhesion to ECM based on upregulation of Bcl-2-like and downregulation of proapoptotic proteins such as Bax or Bim (7-8). FAK is a non-receptor bound tyrosine kinase that regulates adhesion, cell shape, and cell motility by mediating integrin and receptor tyrosine kinas signalling. The SH3-domain-containing adaptor protein p130Cas (Crk-associated substrate) binds to FAK and activates Rac, promoting cell migration (9-10).

To delineate the role of integrins, including CAMs, in CAM-DR/RR signaling upon IR exposure and GSK3 $\beta$ inhibition (by LiCl), we have analyzed genes' level by microarray in CML cell line (K562). This was compared with microarray data of 8Gy irradiated AML cells (KG1a) to find out similarity and differences between two forms of myelogenous leukemia with respect to global genetic response. Specifically, differential expression of integrinsinters alia CAMs was evaluated for influencing survival, adhesion and migration signaling. Since radiation induced cell survival occurs through integrin mediated adhesion, we speculated the enhanced irradiated cell survival upon $\mathrm{LiCl}$ treatment due to integrins' involvement. We found that expression of integrins, $\mathrm{a} 5, \mathrm{aL}$ and $\beta 2$ was increased in K562 (at 8Gy), whereas expression of a4 was decreased with respect to KG1a cells. Few common adhesion genes were found to be upregulated in both $\mathrm{KG1a}$ and $\mathrm{K562}$. $\mathrm{LiCl}$ increased the cell adhesion to fibronectin coated surface; this effect was partially blocked upon integrin a 5 siRNA treatment. This prompted us to identify the role of other molecules in $\mathrm{LiCl}$ mediated enhanced cell adhesion. The highest blockage to adhesion was conferred by integrin $\beta 2$ antibody. Pre-treatment of $2 \mathrm{mM} \mathrm{LiCl}$ also increased the cell migration across transwell membrane in $\mathrm{K} 562$ cells, however, it was inhibited when cells were irradiated, and indicating increased adhesion to transwell insert. The chromatin immunoprecipitation (CHIP) with NFKB antibody suggested role of IL-8 and MMP1 in migration across transwell insert regulated by NFKB. The LiCl and IR exposure synergistically enhanced TGF- $\beta$, $\beta$-catenin and CDC42 genes, involved in survival, adhesion and migration signaling. Further the cytotoxic effect of Imatinib was synergized in the presence of CD18 antibody, undermining the pro-survival effects of $\mathrm{LiCl}$. This study suggests cautious use of $\mathrm{LiCl}$ in $\mathrm{CML}$ patients, where it may lead to metastasis and increased tumor volume.Based on the results, we propose evaluation of synergistic use of $\beta 2$ integrin inhibitors with TKI (such as Imatinib)given prior to stem cell transplantin $\mathrm{CML}$ to decrease its remission with radiotherapy.

\section{Materials And Methods}

\section{Microarray}


A number of $1 \times 10^{6} \mathrm{KG} 1$ a cells (human) were irradiated at $8 \mathrm{~Gy}$ at a radiation dose of $1.557 \mathrm{~Gy} / \mathrm{min}$ with $1 \mathrm{hr} \mathrm{LiCl} \mathrm{pre-treatment.} \mathrm{After} \mathrm{48hr,} \mathrm{cells} \mathrm{were} \mathrm{resuspended} \mathrm{in} \mathrm{500 \mu l} \mathrm{of} \mathrm{RNALater( \# 7020,} \mathrm{Ambion,}$ ThermoFisher Scientific, USA) and incubated on ice for $3 \mathrm{hr}$. The microarray was performed at Genotypic Technologies (Agilent) Pvt. Ltd, Bangalore, India. Briefly, RNA was isolated using RNeasy Mini Kit (Qiagen) and quantified in Nanodrop Spectrophotometer. Following reverse transcription of RNA into CDNA, Cy3-labeled cRNA was produced by in vitro transcription and hybridized to human whole genome array chip (Human Whole Gene Expression Microarray, $4644 \mathrm{~K}$ array, Agilent Technologies). The fluorescent images were scanned and acquired using feature extraction software (v10.5, Agilent technologies). The microarray data was deposited in GEO database (accession no.: GSE73486 http://www.ncbi.nlm.nih.gov/geo/). Similarly, the microarray data of K562 irradiated at 8Gy was obtained from the GEO database (accession no.: GSE7505 https://dtp.cancer.gov/discovery_development/nci$60 /)$.

\section{Microarray expression data analysis}

The probes which were detected in all the replicates were considered for further data analysis. In GeneSpring GX11, the data were normalizedby percentile shift normalization method. After normalization, the data were $\log _{2}$ transformed. The average log2 ratio with $p$-value $\leq 0.05$ was used to identify differentially regulated genes. To identify biological processes and molecular functions associated with differentially regulated genes, functional annotation tool in DAVID Bioinformatics Resources 6.7 was used (https://david.ncifcrf.gov/) considering p-value $\leq 0.05$ as significant. Further, the signaling pathways controlled by significantly altered genes were identified in Pathway Miner (http://www.biorag.org/pathway.html), which provided annotation from KEGG, Biocarta and GenMAPP, taking Fisher exact pvalue $\leq 0.05$ as significant.

\section{Principal component analysis (PCA)}

To identify the common clustered and correlated genes, the samples were clustered by implementing the PCA. One advantage of PCA is that the principal components are always orthogonal (uncorrelated), whereas other methods often produce redundant correlated clusters. The parameters set for PCA clustering were, $Z$ value $=8.0$, error model $=4$, error variance $=500$, Bayesian degree of freedom $=10, F D R$ threshold $=0.05$. The data were uploaded as $\log _{2}$ transformed values.

\section{Network generation}

The GeneMANIACytoscape plugin was used for predicting gene functions(11). The genes involved in cell adhesion classification were input in GeneMANIA to find out interactions among them. The resulting predicted network of functional relationships among query and predicted genes was then used as an annotated Cytoscape network for analysis. Further,ClueGO app(http://www.ici.upmc.fr/cluego/cluegoDownload.shtml) was implemented to improve biological interpretation and functionally organize GO and pathway term network. 


\section{Cell lines, antibodies and radiation}

All cell lines used in this study were cultured in cell culture medium containing foetal bovine serum (FBS \#10270, GIBCO, Invitrogen, USA) and antibiotics solution (\#A002A-50ML, HIMEDIA, India) at $37^{\circ} \mathrm{C}$ (in a $5 \%$ CO2 atmosphere). K562 cells (human, NCCS Pune) were cultured in 10 percent FBS containing IMDM (\#17633, Sigma, USA) while KG1a cells were grown in 20 percent FBS containing IMDM (\#17633, Sigma, USA). Bhabhatron II teletherapy unit with Cobalt 60 radiation source (Panacea, India) at $80 \mathrm{~cm}$ signal to source distance and $35 \times 35 \mathrm{~cm} 2$ field size was used for irradiation. LiCl (\#A6286, 0100, Applichem, $\mathrm{GmbH}$, Germany) was used to pre-treat cells at concentrations of 2-32mM. Throughout the experiment, it was present. Fibronectin (\#F2006, Sigma, USA) in concentrations ranging from 1 to $10 \mathrm{~g}$ was coated on cultureware. CD54 (\#555511), CD49D (\#555502), CD49E (\#555615), CD29 (\#556048), CD18 (\#556084), and CD41B (\#555469) antibodies were purchased from BD USA and used as directed by the manufacturer. Unless otherwise stated, all other chemicals were purchased from Sigma in the United States.

\section{Cell viability and adhesion}

Cells were pretreated with $2 \mathrm{mMLiCl}$ for $1 \mathrm{hr}$ before radiation. After $48 \mathrm{hr}$, the adhered cells and those in the

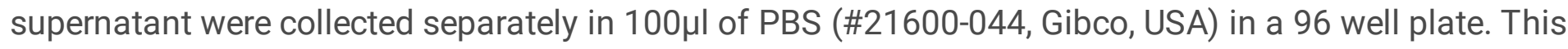
was followed by addition of $10 \mu$ l of Prestoblue reagent (\#A13261, Invitrogen, USA). This reagent is quickly reduced by metabolically active cells, providing a quantitative measure of viability and cytotoxicity. After $1 \mathrm{hr}$ of incubation, fluorescence was recorded at a wavelength of $590 \mathrm{~nm}(560 \mathrm{~nm}$ excitation).

To check interaction of cells with fibronectin, 24 wells plates were coated with different concentration of fibronectin. In a few wells, about $1 \mu$ of 1:100 diluted anti-CD49e antibodywas added and incubated for $30 \mathrm{~min}$ at $37^{\circ} \mathrm{C}$. Rinsed wells with PBS and plated $6 \times 10^{4}$ cells/well of the coated plates. Plates were incubated for $90 \mathrm{~min}$ in a $\mathrm{CO}_{2}$ incubator. After incubation, rinsed wells with PBS four times gently. Added $100 \mu$ l of PBS in each well and mixed $20 \mu$ l of MTS reagent (\#G5421, Promega, USA) in each well. Incubated at $37^{\circ} \mathrm{C}$ for $1-4 \mathrm{hr}$ in $\mathrm{CO}_{2}$ incubator. Recorded absorbance at $490 \mathrm{~nm}$. In a separate experiment, K562 adhesion to culture plate was estimated similarly upon blocking of surface receptors for CAMs belonging to lg superfamily (CD54), and integrins (CD49D, CD49E, C11a, CD29, CD18 and CD41B). The adhered cells were collected and assayed for reduction of PrestoBlue reagent.

To observe the effect of combined treatment of CD18 antibody, LiCl and Imatinib on K562 cells, viability assay was performed with MTT reagent. A total of $1 \times 10^{5} \mathrm{~K} 562$ cells were pelleted in U-shaped wells of a 96 well plate in DMEM containing 10\% FBS. Added CD18 antibody/ $\mathrm{LiCl}(2 \mathrm{mM}) /$ their combinations to the individual wells containing K562 cells. The Imatinib drug was added to each well at $1 \mu \mathrm{M}$ or $10 \mu \mathrm{M}$ concentration to assess the combined effect of treatments on K562 cell's growth. The culture plate was centrifuged at $100 \mathrm{rpm}$ for $10 \mathrm{~min}$. Incubated cells for 3 days to induce spheroid formation. After 3 days, $10 \mu \mathrm{l}$ of MTT reagent was added in each well. Incubated the plate for $4 \mathrm{hr}$. Added $50 \mu \mathrm{l}$ of MTT solvent 
(DMSO and Isopropanol in 1:1 ratio) to each well to dissolve the formazen crystals. Measured absorbance at $595 \mathrm{~nm}$.

\section{Flow cytometry}

Exponentially growing $1 \times 10^{6}$ cells with or without radiation and $\mathrm{LiCl}$ pre-treatment were collected after $48 \mathrm{hr}$ of incubation. Cells were washed with PBS and fixed in $4 \%$ PFA for $20 \mathrm{~min}$ at $4^{\circ} \mathrm{C}$. Labeled cells with CD49e-PE (\#555617, BD, USA), CD18 and CD54 antibody for $1 \mathrm{hr}$ at $4^{\circ} \mathrm{C}$. The cells were then stained with 1:100 diluted FITC labeled secondary antibody (\#sc-2080, Santa Cruz, USA).Again, washed the cells with PBS and analyzed in flow cytometer (BD FACS Caliber).

\section{Immunoprecipitation of Serine 9 phosphorylated GSK3 $\beta$}

Briefly, after $\mathrm{LiCl}$ and radiation treatment as described earlier, K562 cells were washed with PBS. All subsequent steps were performed on ice. Added $1 \mathrm{ml}$ of RIPA lysis buffer/ $40 \mathrm{mg}$ ( $5 \times 10^{6}$ cells) of wet cell pellet. Further, added $10 \mu \mathrm{l}$ of protease inhibitor cocktail (\#5871, Cell Signaling Technology). Incubated the mixture on ice for $15 \mathrm{~min}$. The lysate was centrifuged at $14000 \mathrm{xg}$ for $15 \mathrm{~min}$. The lysate was transferred to an eppendorf and incubated with $10 \mu \mathrm{l}(2 \mu \mathrm{g})$ of GSK3 $\beta$ antibody (Ser-9)(A component ofPhospho-Akt

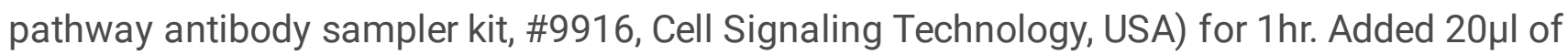
resuspended volume of Protein A/G Plus-agarose beads (\#sc-2003, Santa Cruz Biotechnology Inc.). Incubated at $4^{\circ} \mathrm{C}$ on a rocker platform for $1 \mathrm{hr}$. Collected the immunoprecipitate by centrifugation at $2500 \mathrm{rpm}$ for $5 \mathrm{~min}$ at $4^{\circ} \mathrm{C}$. Washed pellet four times with $1 \mathrm{ml}$ of PBS/RIPA buffer. Resuspended the pellet in $40 \mu \mathrm{l}$ of $1 \mathrm{X}$ electrophoresis sample buffer. Boiled sample for $2-3 \mathrm{~min}$ and analyzed $20 \mu \mathrm{l}$ aliquot in SDSPAGE.

\section{SiRNA transfection}

A total of $1 \times 10^{6} \mathrm{~K} 562 \mathrm{cells} / \mathrm{ml}$ were suspended in OptiMEM (\#31985, Gibco, Thermo Fisher Scientific, USA). The integrin a5 siRNA (\#sc-29372, Santa Cruz, USA) was transfected into K562 cells at a concentration of $40,80,120,160$ and $200 \mathrm{nM}$ with $10 \mu$ lipofectamine $2000 \mathrm{CD}$ reagent (\#52888, Invitrogen, USA) according to manufacturer's recommendations. After $72 \mathrm{hr}$ of incubation, cells were treated with $2 \mathrm{mM} \mathrm{LiCl}$ for $1-2 \mathrm{hr}$ and plated on fibronectin coated wells $(10 \mu \mathrm{g} / \mathrm{ml})$. The adhesion of cells to fibronectin coated plates was measured with MTT reagent (\#M5655, Sigma, USA).

\section{Immunostaining}

The $\mathrm{LiCl}$ and IR treated $\mathrm{K} 562$ cells were incubated for $48 \mathrm{hr}$. Then cells were fixed in $0.5 \%$ paraformaldehyde for $20 \mathrm{~min}$ at $4^{\circ} \mathrm{C}$. For labeling, CD18 antibody (1:1000 diluted) and PE labeled secondary antibody (1:1000 diluted) was incubated with cells. Subsequently added Prolong gold antifade reagent with DAPI (\#8961 Cell Signaling Technology, USA). This was followed by mounting of cells on a slide with $20 \mu \mathrm{l}$ of $90 \%$ glycerol. Visualized fluorescence of cells under microscope (Olympus, India).

\section{Transwell migration assay}


K562 cells were starved for $24-48 \mathrm{hr}$ prior to assay by growing in serum free medium. A total of $1.6 \times 10^{5}$ cells were dispensed in 12 well $(0.8-3 \mu \mathrm{m})$ transwell insert in $1 \mathrm{ml}$ of serum free IMDM. In another experiment, cells were irradiated at 10 and 15Gy or blocked with CD18 antibody for $1 \mathrm{hr}$ before dispensing into transwell insert. Filled wells of 12 well plate with $1 \mathrm{ml}$ of $10 \%$ IMDM medium and placed transwell insert in the well. Covered the plate and incubated for $48-72 \mathrm{hr}$ at $5 \% \mathrm{CO}_{2}$. After incubation, placed the insert into a clean well containing $225 \mu$ l of pre-warmed cell detachment solution (\#ECM505, QCM Chemotaxis cell migration assay kit) for $30 \mathrm{~min}$ at $37^{\circ} \mathrm{C}$. Dislodged cells completely from the underside by gently tilting the insert back and forth several times during incubation. The insert was discarded thereafter. Also collected the cells migrated to the lower chamber. Mixed cells dislodged from insert and from lower chamber. Cells were resuspended in $100 \mu \mathrm{l}$ of PBS and $100 \mu \mathrm{l}$ of MTT was added. After $30 \mathrm{~min}$ of incubation in dark at room temperature (RT), added MTT solvent and again incubated for $15-30 \mathrm{~min}$. Read absorbance at $560 \mathrm{~nm}$ in a spectrophotometer.

\section{Chromatin immunoprecipitation}

The $\mathrm{LiCl}$ and IR treated cells were harvested after $48 \mathrm{hr}$ of incubation and their chromatin was immunoprecipitated with $5 \mu$ l of NFKB antibody (\#N8523-2ml Sigma, USA) as per manufacturer's instructions using SimpleChIP® Enzymatic Chromatin IP Kit (\#9002, Cell Signaling Technology, USA). This was followed by qPCR for IL7, IL8 and MMP1 genes using SYBR green (\#K0222, ThermoFisher Scientific, USA).

Briefly, to crosslink proteins to DNA in the growing cells, $540 \mu$ of $37 \%$ formaldehyde was added to each sample.Mixed and incubated for $10 \mathrm{~min}$ atRT. A total of $2 \mathrm{ml}$ of $10 \mathrm{X}$ glycine solution was added to each dish, mixed briefly, and incubated for $5 \mathrm{~min}$ at RT. Then cells were centrifuged at $500 \mathrm{~g}$ for $5 \mathrm{~min}$ at $4{ }^{\circ} \mathrm{C}$ and washed twice with ice-cold PBS. Then cells were resuspended in $1 \mathrm{ml}$ ice-cold 1 X Buffer A with dithiothreitol (DTT) and Protease Inhibitor Cocktail (PIC) per immunoprecipitation preparation (IP prep). This was followed by incubation on ice for $10 \mathrm{~min}$ with intermittent mixing. The nuclei were pelleted by centrifugation at $2000 \mathrm{~g}$ for $5 \mathrm{~min}$ at $4{ }^{\circ} \mathrm{C}$. The nuclei pellet was resuspended in $1 \mathrm{ml}$ of ice-cold $1 \mathrm{X}$ Buffer $\mathrm{B}$ with DTT per IP prep. The step was repeated, and the pellet was resuspended in $100 \mu$ l of 1 X Buffer B with DTT per IP prep. Then $0.5 \mu$ of Micrococcal Nuclease was added per IP prep, mixed by inverting the sample several times and incubated for $20 \mathrm{~min}$ at $37^{\circ} \mathrm{C}$ with frequent mixing to digest DNA to a length of approximately $150-900 \mathrm{bp}$. The reaction was stopped by adding $10 \mu \mathrm{lof} 0.5 \mathrm{M}$ EDTA per IP prep and placing tube on ice for $1-2 \mathrm{~min}$. The nuclei were pelleted by centrifugation at $16,000 \mathrm{~g}$ for $1 \mathrm{~min}$ at $4^{\circ} \mathrm{C}$.

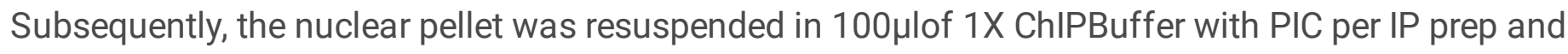
incubated on ice for $10 \mathrm{~min}$. An aliquot of $500 \mu$ lof sample was sonicated with several pulses to break the nuclear membrane. Incubated samples for 30 s on ice between sonication pulses. Further, the lysate was clarified by centrifugation at $9400 \mathrm{~g}$ for $10 \mathrm{~min}$ at $4^{\circ} \mathrm{C}$.

For CHIP, mixed 1X ChIP Buffer and 100 $\mu$ ( $5-10 \mu \mathrm{g}$ of chromatin) of the digested, cross-linked chromatin preparation. An aliquot of the diluted chromatin (10 $\mathrm{\mu l}$ ) was transferred to a microfuge tube. This was designated as $2 \%$ Input Sample. For each immunoprecipitation, transferred 500 $\mu$ lof the diluted chromatin 
to a $1.5 \mathrm{mlmicrocentrifuge} \mathrm{tube} \mathrm{and} \mathrm{added} \mathrm{immunoprecipitatingNFKB} \mathrm{antibody.} \mathrm{The} \mathrm{IP} \mathrm{samples} \mathrm{were}$

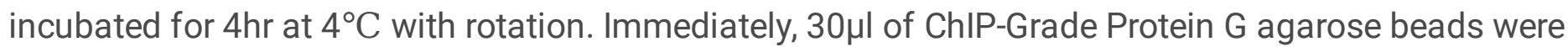
added to each IP reaction and again incubated for $2 \mathrm{hr}$ at $4^{\circ} \mathrm{C}$ with rotation. The Protein $\mathrm{G}$ agarose beads were pelleted by centrifugation at $3400 \mathrm{~g}$ for $1 \mathrm{~min}$. The pelleted beads were then washed with low salt wash buffer, followed by washing with high salt wash buffer. For elution of chromatin from antibody/Protein $\mathrm{G}$ agarose beads and breaking of cross-links, 150 $\mu$ lof the 1X ChIP Elution Buffer was added to the $2 \%$ Input sample tube and incubated at RT. An equal amount of $1 \mathrm{X}$ ChIP elution buffer $(150 \mu l)$ was added to each IP sample. The chromatin was eluted from the antibody/Protein $\mathrm{G}$ agarose beads complex by gentle vortexing for $30 \mathrm{~min}$ at $65^{\circ} \mathrm{C}$. Pelleted beads in each IP by centrifugation at $3400 \mathrm{~g}$ for $1 \mathrm{~min}$. Finally, eluted chromatin was transferred to a new tube. The cross-links were reversed by adding $6 \mu \mathrm{l}$ of $5 \mathrm{M} \mathrm{NaCl}$ and $2 \mu \mathrm{lProteinase} \mathrm{K}$ and incubating for $2 \mathrm{hr}$ at $65^{\circ} \mathrm{C}$.

This was followed by the isolation of DNA. For this, 750 $\mu$ lof DNA binding buffer was added to each DNA sample and vortexed briefly. Then each sample was transferred to a DNA spin column placed in the collection tube. The spin column was centrifuged at $18,500 \mathrm{~g}$ for $30 \mathrm{~s}$. Added $750 \mu$ lof wash buffer to the spin column and centrifuged at $18,500 \mathrm{~g}$ for $30 \mathrm{~s}$. This was followed by the addition of $50 \mu \mathrm{l}$ of elution buffer to each spin column placed into a 1.5mleppendorf. For DNA elution, the column was centrifuged at 18,500g for 30s. Subsequently, qPCR was performed for GAPDH, IL7, IL8 and MMP1 genes using SYBR green dye (\#K0222, ThermoFisher Scientific, Waltham, MA) (see Supplementary Table 1 for PCR primers sequence).

\section{RT-PCR}

Approximately $1 \times 10^{7}$ cells were suspended in $600 \mu$ of lysis buffer supplemented with $2 \mathrm{mM}$ DTT provided with Gene JET RNA purification kit (Thermo Scientific, USA). This was followed by addition of 360ul of ethanol (96-100\%). The cell lysate was transferred to RNA purification column and washed with wash

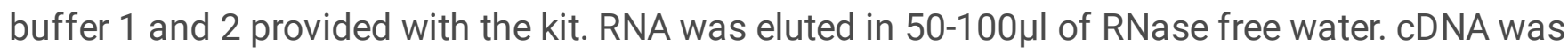
synthesized from the eluted RNA using cDNA synthesis kit (Fermentas, USA). Mixed the following reagents, template DNA $(0.1 \mathrm{ng}-5 \mu \mathrm{g})$, random hexamer primer, $5 \mathrm{X}$ reaction buffer, ribolock RNase inhibitor, $10 \mathrm{mM}$ dNTP and Revert Aid M-MuLV Reverse Transcriptase followed by water. The reaction was performed in a thermal cycler for $5 \mathrm{~min}$ at $25^{\circ} \mathrm{C}, 60 \mathrm{~min}$ at $42^{\circ} \mathrm{C}$ and $5 \mathrm{~min}$ at $70^{\circ} \mathrm{C}$. An aliquot of $2 \mu \mathrm{l}$ of reverse transcribed product was used to set up qPCR using SYBR green (\#K0222, ThermoFisher Scientific, USA) for detection of amplified gene in RT-PCR machine (\#CFX96, Bio-Rad, USA).

\section{Statistical analysis}

The data were presented as mean \pm standard deviation. Student's t-test was used to compare data between groups. Differences between the groups at $5 \%$ were considered significant $(p \leq 0.05)$. For the calculation of log fold change in RT-PCR, the $\triangle C T$ and $\triangle \triangle C T$ values were calculated(12). 
Where $\Delta \mathrm{C}_{\mathrm{T}}=\mathrm{C}_{\mathrm{T}}$ (geneof interest) $-\mathrm{C}_{\mathrm{T}}$ (housekeepinggene),

$\Delta \Delta \mathrm{C}_{\mathrm{T}}=\Delta \mathrm{C}_{\mathrm{T}}$ (treated sample) $-\Delta \mathrm{C}_{\mathrm{T}}$ (untreatedsample), and

$\mathrm{C}_{\mathrm{T}}$ (cycle threshold of the sample) $=$ Indicates cycle number, where the fluorescence generated by the PCR product is discernible from the background noise.

\section{Results}

\section{IR activates adhesion inducing genes in K562 cells: Microarray data analysis}

The K562 cells, while growing, adhere to the plastic surface but do not spread. At high density these cells grow in bunches with coexistence of suspension and adherent populations (13). While KG1a (Human, NCCS pune) cells do not show these characteristics in culture, nevertheless, a small percentage of cells have been reported to attach to the growing surface (14).To find the involvement of cell adhesion molecules in radiation induced survival and disparity between K562 and KG1a adhesion, the microarray of irradiated KG1a cell was performed. Cluster analysis was performed for all the genes present in the microarray data by using ExAtlassoftware(Figure 1a). KG1a and KG1a8Gy genes were observed to be closely related/ overlapping each other while the genes expression varies in K562 and K5628Gy. Large distance between KG1a8Gy and K5628Gy samples suggested diverse gene expression in both. The strongest pattern of gene expression was represented by the PC1. A large set of genes showed high correlation in PC1, which was both positive (12 genes) and negative (192 genes)(Figure. 1b-d). In PC2, which was orthogonal and unrelated to PC1, showed smaller number of only positively correlated genes (33 genes). The PC3 was orthogonal to PC1 and PC2 and did not show any correlated genes. The unrelated gene expression between K562 and K5628Gy irradiated samples suggests change in genotypic and phenotypic characteristics related to adhesion.

The function of all the adhesion related genes differentially expressed upon radiation was ascertained by using ClueGO app in Cytoscape (Table 1).In KG1a cells, four functionally grouped networks were obtained viz., Cell junction assembly, T-cell co-stimulation, astrocyte development, collagen catabolic process and in K562 cells only two functionally grouped network were obtained viz., positive regulation of smooth muscle cell proliferation andheterophilic cell-cell adhesion (Figure 2). There were several other functions which were upregulated but not grouped to the functional network. In contrast, genes related to heterotypic cell-cell adhesion and cell-substrate junction assembly were down-regulated in KG1a and K562 respectively.

The homotypic cell-to-cell adhesion is shown by cadherins and immunoglobulin superfamily proteins, whereas heterotypic cell-to-cell adhesion is displayed by selectins and integrins. Integrins also display cell to ECM heterotypic interactions. Genes involved inheterotypic adhesion were found to be downregulated in KG1a, suggesting irradiated KG1a cells may less likely to show adhesion while growing. Nonetheless, 
the heterotypic cell adhesion mediated through integrins was upregulated in K562 upon irradiation, indicating that radiation exposure may enhance their adhesion. Among various ontologies, the genes involved in cell adhesion were identified in Pathway miner. The interactions among the genes upon IR exposure were identified inGeneMANIA app in Cytoscape (Figure.3). In KG1a, only five genes were downregulated whereas in K562,eighteen genes were found to be downregulated.

The comparison of genes up-/down-regulated at 8Gy showed many common genes between KG1a and K562. A total of eight genes were upregulated and one gene was downregulated in common (Table 2). Common upregulated genes were ACTN2, CAV1, vWF, CDH15, JAM2, NCAM2, L1CAM and CD28. The common downregulated gene was CD2. Among these, ACTN2 and VWF are cell-to-substrate adhesion molecules; CAV1, CD28 and CD2 regulate T cell function; CDH15, JAM2, NCAM2 and L1CAM are cell-to cell adhesion molecules. This may be reason for small percentage of KG1a cells adherence to the tissue culture plastic while growing. Given that an adherent population of primitive hematopoietic stem/progenitor cells within KG1a is CD29dim, express high levels of CD54, and contain lower levels of ganglioside (GM3). This unique subpopulation is likely responsible for relapse in AML, and represents a target for novel therapeutics for eradicating the resistant AML cells (14). On the other hand, most of the K562 cells at high density adhere to the plastic surface.

\section{Integrins expression upon irradiation}

It has been shown that induction of apoptosis in fludarabine-, etoposide- or bleomycin-treated human leukemia cells was prevented by integrin-mediated adhesion to ECM by upregulation of Bcl-2-like proteins and downregulation of proapoptotic proteins such as Bax or Bim (15). The role of $a 6 \beta 4, a V \beta 6, a 26 \beta 1$ and a5 $\beta 1$ has already been reported to improve the cell survival upon cytotoxic treatment.

In order to find out the difference between integrins expression, the comparison of K562 and KG1a microarray data was done (Figure. 4), which showed $>4$-fold upregulation of ITG $\beta 2$ (integrin $\beta 2$ / CD18),>3-fold for ITGa5 (integrin a5/ CD49e/ VLA-5) and >2.5-fold for ITGaL (integrin aL/ CD11a/p180) in K5628Gy and downregulation of ITG $\beta 1$ (integrin $\beta 1 /$ CD29) and ITGa4 (integrin a4/ CD49d/ VLA-4). In case of KG1a8Gy increase in the expression of $>2.5$-fold for ITGa4, $>3.5$-fold for ITGaL and $>2.4$-fold for ITG $\beta 1$ was observed. The data suggest integrins upregulation upon irradiation.

We further checked experimentally whether expression of ITG 32 (>4-fold expression) increased with radiation. The CD18 protein expression increased significantly along with increase in the radiation dose when $\mathrm{K} 562$ cells were supplemented with $2 \mathrm{mM} \mathrm{LiCl} \mathrm{(Figure} \mathrm{5a).} \mathrm{Whereas} \mathrm{similar} \mathrm{trend} \mathrm{was} \mathrm{not} \mathrm{observed}$ with integrin a5 protein expression in irradiated K562 cells at 8, 10 and 15Gy, with or without LiCl. The improved viability was coincidental with the adhesion of cells to the growing surface. The adhesion of

cells was decreased in the presence of integrins antibodies (Figure 5b), suggesting blocking of cognate receptor and reduced adherence to the growing surface. The maximum decrease in adhesion was seen with CD18 and CD49d blocking antibodies. 
CML progresses from chronic phase to blast crisis by activation of $\beta$-catenin within granulocyte macrophage progenitors. CDNA sequencing of Wnt/ $\beta$-catenin pathway has shown an in-frame splicedeletion of the GSK3 $\beta$ domain in the blast crisis samples(16). The inhibition of GSK3 $\beta$ (by inhibitory phosphorylation at serine 9) with $\mathrm{LiCl}(17)$ or IR releases $\beta$-catenin to promote survival through cyclin D1 and Myc protein. In this signaling, $\beta$-catenin is shown to be essential for survival of leukemic stem cells insensitive to known kinase inhibitors (18). We found in IP assay that the combined LiCl and IR treatment leads to the higher detection of the phosphorylated form of GSk3 $\beta$ at serine 9 (molecular weight= 46kD) in K562 cells (Figure 5c). In KG1a cells, the phosphorylated form of GSk3 $\beta$ was not detected consistently with IR exposure and LiCl treatment.

\section{LiCldoes not enhance cell adhesion only through integrin a5}

Implication of integrins in $\mathrm{K} 562$ adhesion suggests their binding to fibronectin, a component of ECM. Integrins receptor binds to fibronectin,vitronectin, collagen and laminin. When K562 cells were grown at high cell density $\left(\geq 1 \times 10^{7}\right)$, they settle on the growing surface of the plastic plate and form a clump (Fig. 6a). The increasing concentration of fibronectin decreases clump formation; at $50 \mu \mathrm{g} / \mathrm{ml}$ cells settled as a carpeton the growing surface. The presence of fibronectin, perhaps, decreases cell-to-cell contact by binding to integrin receptors and imparting mat formation. This may explain why presence of high fibronectin concentration inhibits tumor formation in vivo(19). KG1a cells did not show change in adhesion to increased fibronectin concentration, whereas K562 adhesion increased along with the concentration of coated fibronectin (Fig. 6b). The blocking of CD49e cell surface receptors with antibody did not inhibit binding to the plastic surface. This indicates that presence of fibronectin will not affect the adhesion of KG1a, and these cells will less likely to showintegrins mediated cell adhesion.

Given that exposure toLiCl improves survival and adhesion, it is likely that increased concentration of LiCl will manifest more cell adhesion. The cell adhesion was seen to be positively correlated with the $\mathrm{LiCl}$ concentration up to $4 \mathrm{mM}$, thereafter, the adhesion decreased (Fig. 6c). The maximum increase in adhesion was seen at $4 \mathrm{mM}(1.28$-fold $)$ and $8 \mathrm{mM}(1.27$-fold $)$ of $\mathrm{LiCl}$ treatment as compared to untreated cells. The $32 \mathrm{mM} \mathrm{LiCl}$ concentration decreases cell adhesion and viability significantly. These results indicate upregulation of CAMs upon $\mathrm{LiCl}$ treatment.

Reportedly adhesion of K562 cells to fibronectin mediated by a5 31 is shown to resist apoptosis after treatment with $\gamma$-radiation (6). In order to find the role of $\mathrm{LiCl}$ in upregulating a5ß1 (CD49e), its expression was checked by flow cytometer in $\mathrm{K} 562$ cells (Fig. 7a,b). LiCl did not show any significant change in $\mathrm{CD} 49 \mathrm{e}$ expression though it increases the adhesion and survival upon irradiation. This data indicated that this effect was not fully attributable to integrin a5. The maximum integrin expression was observed after $48 \mathrm{hr}$ of irradiation without any effect of increased $\mathrm{LiCl}$ concentration from $2 \mathrm{mM}$ to $8 \mathrm{mM}$. Number of dead cells/ debris was also increased at this juncture (Fig. 7c,d). The siRNA mediated knockdown of integrin a5 did not have significant inhibitory effect on cell adhesion to fibronectin coated surface(Fig.7e, 
f).Altogether, these studies indicate role of other adhesion molecules in $\mathrm{LiCl}$ mediated adhesion.

\section{Role of other CAMs in LiCl mediated adhesion}

CAMs belong to Ig superfamily (PECAM1, ICAM1, ICAM2, VCAM), integrins $\{a$ and $\beta(\beta 1, \beta 2, \beta 3)\}$, cadherins (NCAM), selectins (ELAM1, GMP140, MEL14) and addressins. They are also classified as calcium-independent and calcium-dependent, which exert their action by homophilic and heterophilic types of interaction. Our microarray data analysis shows highest CD18 expression level in K562 and K5628Gy samples, followed by other CAMs(Fig. 8a).

CD18 expression was found to be significantly increased in cells given combined treatment of LiCl and IR exposure after $48 \mathrm{hr}$ as shown earlier in Figure $5 \mathrm{a}$ (Fig. 8b-c). However, this trend was seen only after $48 \mathrm{hr}$ of incubation with $\mathrm{LiCl}$ and IR exposure. The $\beta 2$ integrin activates SYK/STAT3/5 signaling axis (20) and promotes proliferation of AML cells. In addition, signaling through this integrin prolongs eosinophil survival (21). Our study suggests a significant role of $\beta 2$ integrin in improving cell adhesion and perhaps cell survival through CAM-RR.

CD54 (ICAM1) serves as a ligand/counter-reception for CD11b/CD18, expressed on a variety of cells including endothelial cells; therefore it appears to be a likely candidate for the molecule that might trigger cell viability (22). CD54 antibody blocked cells did not show significant increase in its expression even upon combined LiCl and radiation treatment(Fig.9), suggesting absence of LFA-1 (CD11A/CD18) - ICAM1 pathway in preventing cell death (23).

\section{LiCl promotes migration but not in irradiated cells}

Integrin dysregulation contributes to several diseases, including squamous cell carcinomas and other tumors(24). Changes in integrin expression patterns differentially affect tumor invasion and metastasis. For example, upregulation of a6 $\beta 4$ integrins has been reported in skin and head and neck tumors and might account for an increased adhesion of tumor cells in the process of metastasis. On the other hand, reduced integrin levels promote cell detachment from the primary tumor and invasive growth. Besides, gamma-ray irradiation impairs dendritic cell migration by CCL19 by down-regulation of CCR7 and induction of cell apoptosis(25). Whether CD18 upregulation on $\mathrm{LiCl}$ and radiation treatment affects cell migration, the trans-well migration assay was performed(Fig. 10a). IR exposure and CD18 antibody blocked (1:100 diluted) cells migration was significantly decreased as compared to control. The presence of $\mathrm{LiCl}$ with radiation does not improve cell migration,nevertheless, presence of $\mathrm{LiCl}$ significantly reduced migration of cells along with blocking of CD18 receptors. Radiotherapy employed to eradicate CML cells would likely to decrease cell metastasis. The monoclonal antibody against CD18 may also be tested to reduce invasiveness of myeloid cancers.

Aside from CD18, the well-known migration and survival related genes IL7, IL8 and MMP1 and their regulation by radiation sensitive transcription factor NFKB was also analyzed in CHIP assay (Figure 10b). 
The loss of IL-7 mRNA by CLL cells coincides with apoptosis induction, indicating itsdegradation during apoptosis induction and serving as a viability factor (26). On top of that IL-7 decreases ECM production in subconjunctival fibroblasts activated by exogenous TGF- $\beta 1$ and increases Smad 7 (inhibitory Smad) expression, which inhibits TGF- $\beta /$ Smad signal. NFKB, which promotes breast cancer cell migration and metastasis by inducing the expression of the chemokine receptor CXCR4 (27) did not significantly bind to IL7 promoter as observed in CHIP assay. IL-8 has been shown to play an important role in tumor growth, angiogenesis, and metastasis. PI3K-Rac1/RhoA signaling pathway plays a vital role in IL-8 induced endothelial cell migration (28). The binding of NFKB to IL8 gene was significantly decreased in the presence of $\mathrm{LiCl}$ with/without radiation.MMP-1 confers proliferative, migratory, and anti-apoptotic property to alveolar epithelial cells, we found that the binding of NFKB was significantly increased with MMP-1 promoter.

Largely, these data suggest that $\mathrm{LiCl}$ does not impinge upon the binding of NFKB to IL7, whereas $\mathrm{LiCl}$ alone or its combination with IR exposure decreases IL8 expression by NFKB thereby decreasing migration as seen in transwell migration assay. Contrarily,NFKB binding to MMP1 promoter increases at Li10Gy treatment, likely responsible for survival even upon IR exposure.

\section{$\mathrm{LiCl}$ and IR induce downstream targets of $\beta 2$ integrin}

At molecular level, $\beta 2$ integrin activation through its cognate receptor signals cell migration through noncanonical TGF $\beta$ pathway (29), whose downstream targets include PI3K and CDC42, which regulate the process of epithelial-mesenchymal transition (EMT). The transcript level of $\beta$-catenin, PI3K, CDC42 and TGF $\beta$ was found to be significantly induced upon concerted LiCl and IR exposure (Figure 11a), suggesting simultaneous Wnt/ $\beta$-catenin $(30,31)$ and non-canonical TGF $\beta$ pathway upregulation in supporting the CML spread, conceivably, leading to blast crisis and survival of leukemic stem cells (15). In addition, pro-apoptotic genes p53 and Bax were notably decreased with the same treatment. As the response of CML to TKI treatment is currently monitored by cytogenetic and qPCR analysis of BCR/ABL1 transcription (32), the panel of adhesion and migration related genes found in our study may add to the prognostic and diagnostic markers for CML progression and remission.

Imatinib is an inhibitor of BCR/ABL, PDGF and c-kit protein tyrosine kinase (33). It is indicated in Philadelphia chromosome positive CML, c-kit (CD117) positive unresectable and/or metastatic malignant gastrointestinal stromal tumors (GIST). Its therapeutic dose range varies from $400 \mathrm{mg}-800 \mathrm{mg} / \mathrm{day}$. The combined treatment of Imatinib $(10 \mu \mathrm{M})$ and CD18 blocking antibody significantly $\left({ }^{*} \mathrm{p} \leq 0.05\right)$ decreased $\mathrm{K} 562$ cell viability(Figure 11b). This effect was pronounced in the absence of $\mathrm{LiCl}$, since $\mathrm{LiCl}$ has prosurvival effect on $\mathrm{K} 562$ cells. Our results indicate that $\beta 2$ integrin antagonism, in addition to Imatinib treatment, is likely to sensitize the CML for chemotherapy. 


\section{Discussion}

Cell survival depends on multiple signaling inputs like growth factors, nutrients, and attachment to the surrounding cells and ECM components. Cell-ECM interactions(35) through integrins and growth factor receptors tightly controls critical cell functions such as cell survival, proliferation, differentiation, adhesion, and migration (36). The IR generates reactive oxygen species, which leads to ECM remodeling and cell adhesion through the activation of proteases, soluble cytokines and growth factors. Integrins and adhesion of cells to ECM confer higher resistance to ionizing radiation and cytotoxic drug, a phenomenon known as cell adhesion mediated radiation resistance (CAM-RR) and cell adhesion mediated drug resistance (CAM-DR) (36-37).

K562 cells show distinct plastic-adherent (K562/Adh) and nonadherent (K562/NonAdh) subpopulations. $B C R-A B L$ mRNA was found to be upregulated in K562/Adhas compared to K562/NonAdh cells in both single cell and bulk population analyses(13). The treatment with imatinib reduces cell viability more rapidly in K562/NonAdh compared with K562/Adh cells. On the other hand, KG1a is a differentiationresistant $A M L$ cell line containing a primitive population of $C D 34^{+} C D 38^{-}$cells. While growing, the majority of KG1a cells remain in suspension, while a small percentage adheres to the tissue culture plastic (AdhKG1a)(14).To analyze the effect of IR on CAMs in both the cell lines, the microarray data of 8Gy irradiated $\mathrm{K} 562$ cells (K5628Gy) was extracted from $\mathrm{NCl} 60$ cell line data (https://dtp.cancer.gov/discovery_development/nci-60/). This was compared with microarray data of 8Gy exposed KG1a cells (KG1a8Gy),whose "Minimum Information About a Microarray Experiment" (MIAMI) compliant data were deposited in the GEO database (GSE73486) (http://www.ncbi.nlm.nih.gov/geo/). Significant biological process $(p<0.05)$ and molecular functions represented by differentially regulated genes were identified in DAVID. Whereafter, the involvement of altered genes in signaling pathways was found using Pathway Miner. The PCA was performed to elucidate the common clustered genes in between KG1a and K562, prior and post IR. Further, genes involved in cell adhesion ontology were input in GeneMANIACytoscape app (http://www.genemania.org/plugin/) to predict interactions among them and to generate network for analysis. The network was later organized as per Gene Ontology term in ClueGO app to improve biological interpretation.

On comparing microarray data of K562 and KG1a cells, genes in adhesion ontologies were found to be upregulated in K5628Gy in which integrins play a part. In contrast, genes related to collagen catabolic process were upregulated and heterotypic cell-cell adhesions were downregulated in KG1a. These alterations in CAMs upon IR in CML are likely to contribute to the development of CAM-RR phenotype in $\mathrm{CML}$. The $\beta 2$ integrin level was measured to be highest among the representative members from CAMs family. This observation was consistent with the previous studies in which role of $\beta 2$ integrin in prevention of apoptosis induction in chronic lymphocytic leukemia B cells is documented(35). Moreover, $\beta 2$ integrin hypomorphic mice implanted tumors are shown to be more sensitive to radiation in earlier studies(40), corroborating its upregulation as a radiation response in CML. 
Given that GSK3 $\beta$ also plays a role in integrin signaling and regulates attachment to fibronectin and causes CAM-DR(2), its inhibition with $\mathrm{LiCl}$ did not appreciably increased well-known integrin a5 (CD49e) expression in our study. However, K562 attachment increased proportionally with fibronectin used for coating culture dish. In addition, the siRNA knockdown of integrin a5 had no effect on LiCl mediated cell adhesion, indicating role of other CAMs in this phenomenon. The combined treatment of both GSK3 $\beta$ inhibitor ( $\mathrm{LiCl}$ ) and IR was found to have more positive effect on integrin $\beta 2$ expression as compared to CD49e. This also improved adhesion of K562 cellswith increase in phosphorylated form of GSK3 $\beta$ at serine 9. The significant increase in integrin $\beta 2$ level in CML cells after IR exposure likely to confer CAM$\mathrm{RR}$ and it reiterates the fact that even $<1 \%$ residual leukemic cells after initial radiotherapy increases the incidence of its relapse(2). Interestingly, the cells blocked with anti- $\beta 2$ integrin/CD18 antibody showed decrease in $\mathrm{LiCl}$ induced adhesion among CAMs andintegrins.Data in variety of normal and transformed human cell lines have indicated increased cell adhesion based on radiation dose-dependent upregulation of $\beta 1, \beta 3$ and $\beta 5$ integrins, which confers higher resistance to IR and cytotoxic drug (3). In this study, we observed highest expression of integrin $\beta 2$ among CAMs upon IR and $\mathrm{LiCl}$ exposure, consequent upon microarray data analysis. This likely account for non-adhesiveness of KG1a (AML) upon same treatment in contrast to $\mathrm{K} 562$ cells (CML) and, observation of CAM/RR phenomenon in $\mathrm{K} 562$ cells only. The $\beta 2$ protein expression was higher vis-a-vis integrin a5, signifying the $\beta 2$ integrin importance in the development of therapy resistant CML.

$\beta 2$ integrin (LFA1), a 90-95kD transmembrane protein, associates non-covalently as a heterodimer with a chain of CD11a, CD11b or CD11c. The CD18 is expressed on lymphocytes, monocytes and weakly on granulocytes. LFA1 has been shown to play an important role in homotypic and heterotypic cellular adhesion in immune and inflammatory responses. In our study it is found to be involved in cell-substrate/ matrix interaction and implied cell survival upon irradiation. The recognition that $\beta 2$ integrin are involved in CAM-RR would lead to novel therapeutic approaches for other pathologies where $\beta 2$ integrin is involved, such as skin inflammation (for neutrophil inhibition), increased survival in animal models of septic shock and amelioration of tissue damage caused by an ischemic-reperfusion injury (41). However earlier studies concluded that ICAM1 did not serve as an anti-apoptotic signal for CLL B cells.

Integrins overexpression/ loss has been known to contribute to several diseases (including squamous cell carcinoma), which differentially affect tumor invasion and migration. In our study, IR and/or LiCl also induced TGF $\beta$ transcription, which was also likely responsible for enhanced adhesion and migration. TGF $\beta$, specifically, has a predictive role in IR tumor response because its high plasma level indicates major risk of developing post-radiation fibrosis (18). Clinical trials of integrin inhibitors have shown low toxicity in patients, which has lead to combination therapy of integrin inhibitor subsuming chemo- or radio-therapy. Use of $\beta 2$ integrin inhibitors could be proved useful in $\mathrm{CML}$ and other cancers e.g., $\mathrm{NCI} 60$ cells(42)in synergism with other therapies with greater efficiency and less toxicity due to conservation of normal tissue.To find out changes in $\beta 2$ integrin in diverse cancer types, its transcript level was checked across all NCl 60 cell lines (Figure 12a). The $\beta 2$ integrin's global genetic response is suggestive of strong expression among various cancers and higher expression upon multi-fractionated radiation exposure (used in radiotherapy) with respect to single radiation dose in endothelial cells. However, apart from 
integrin $\beta 2$, the collective role of CAMs cannot be undermined in CAM-RR and metastasis of CML due to their likely involvement in converting therapy responsive to resistant CML upon therapeutic IR exposure and correlating them with poor clinical outcome.

Mechanistically,IR activates $\beta 2$ integrin through direct/ indirect activation(Figure 12b). The signal from $\beta 2$ integrin percolates down through ILK, FAK (3) and CDC42 (16) to improve CAM-D/RR, cell survival, proliferation, and migration. Simultaneously, TGF $\beta$ activation upon IR exposure activates PI3K and CDC42. The GSK3 $\beta$, which is downstream of PI3K, also gets inactivated by ILK and LiCl exposure. Therefore, $\beta$-catenin and $\mathrm{Bcl}-2$ are rendered free to improve cell survival and proliferation. Active GSK3 $\beta$ binds to and promotes its action, which subsequently upregulates Bax and downregulates Bcl-2 (17). Nevertheless, long-term LiCl treatment suppressed p53 and Bax expression but improves Bcl-2 expression(18). Induction of apoptosis in fludarabine, etoposide or bleomycin treated human leukemia cells is shown to be prevented by integrin-mediated adhesion to ECM based on upregulation of Bcl-2 like proteins and downregulation of Bax. The tyrosine kinase FAK is also activated in integrin signaling, regulating adhesion, and cell shape and cell motility. It leads to F-actin polymerization and improved cell adhesion and migration. FAK null mice showed disturbed microtubule polarization and reduced migration. These mechanisms collaterally are likely responsible for $\beta 2$ integrin effects observed in this study (3).

In summary, this study fosters the rationale of using $\beta 2$ integrin inhibitors and repurposing of currently available $\beta 2$ antagonists being tested in tumor spread(20), in ischemia (LeukArrest and Erlizumab) and in acute myocardial infarction (Erlizumab and Abeiximab) (3). Moreover, the findings suggest contraindication of GSK3 $\beta$ inhibitor and propose $\beta 2$ integrin antagonism in CML therapy when TKI efficacy is not improved by the addition of an adjuvant (1).

\section{Abbreviations}

AML: Acute myeloid leukemia

APP: Acute-phase plasma protein

BAX: Bcl-2 associated $\mathrm{x}$, apoptosis regulator

Bcl-2: B-cell lymphoma 2

BCM1: $C D 48$

$B C R / A B L:$ Breakpoint cluster region protein/ Abelson

$C A M / D R-R R$ : Cell adhesion-mediated drug resistance/ radiation resistance 
CCL 19: Chemokine (C-C motif) ligand 19

CCR: C-C chemokine receptor

CD106: VCAM1

CD11a: integrin aL

CD18: integrin $\beta 2$

CD29: integrin $\beta 1$

CD31: PECAM1

CD41B: integrin a2B

CD49D: Integrin a4/ VLA-4

CD49e:Integrin a 5/ VLA-5

CD54: ICAM1

CD62E: E-selectin

CD62P: P-selectin

CDC42: Cell division control protein 42

CHIP/ Chip: Chromatin immunoprecipitation

CLL: Chronic lymphocytic leukemia

CML: Chronic myelogenous leukemia

CTNNB1: Catenin Beta 1

CXCR-4: C-X-C chemokine receptor type 4

DAPI: 4',6-diamidino-2-phenylindole

DMEM: Dulbecco's modified eagle's medium

DMSO: Dimethyl sulfoxide

dNTP: Deoxyribonucleotide triphosphate

DTT: Dithiothreitol 
ECAM1: Epithelial cell adhesion molecule-1

ECM: Extracellular matrix

EDTA: Ethylenediaminetetraacetic acid

FACs: Fluorescence-activated cell sorting

FAK: Focal adhesion kinase

FBS. Fetal bovine serum

FDR: Functional divergence ratio

FITC. Fluorescein isothiocyanate

GAPDH: Glyceraldehyde-3-phosphate dehydrogenase

GenMAPP: Gene map annotator and pathway profiler

GEO: Gene expression omnibus

GIST: Gastrointestinal stromal tumor

GMP-140 Granule membrane protein 140

GO: Gene Ontology

GP1b: Platelet glycoprotein $1 b$

GSE: Genomic spatial event database

GSK-3 $\beta$ : Glycogen synthase kinase 3 beta

ICAM-1: Intercellular adhesion molecule 1

ICAM-2: Intercellular adhesion molecule 2

IL 7: Interleukin 7

IL 8: Interleukin 8

ILK: Integrin-linked kinase

IMDM: Iscove's modified dulbecco'smedium

Integrin a5: CD49e 
IP: Immunoprecipitation

IR: lonizing radiation

ITG $\beta 2$ : Integrin beta 2

KEGG: Kyoto Encyclopedia of genes and genomes

LFA-1: Lymphocyte function-associated antigen 1

LFA3: Lymphocyte function associated antigen 3

LiCl: Lithium chloride

MMP: Matrix metalloproteinase

M-MuLV: Moloney Murine Leukemia Virus

MTT: 3-(4,5-dimethylthiazol-2-yl)-2,5-diphenyl tetrazolium bromide

NCAM: Neural cell adhesion molecule

$\mathrm{NCl}$ : National cancer institute

NFKB: Nuclear factor kappa-light-chain-enhancer of activated B cells

NIA: National institute of ageing

PBS: Phosphate buffered saline

PCR: Polymerase chain reaction

PDGF: Platelet-derived growth factor

PE: Phycoerythrin

PECAM-1: Platelet endothelial cell adhesion molecule

PFA: Paraformaldehyde

PI3K: Phosphoinositide 3-kinase

PIC: Protein inhibitor cocktail

PL: Platelet Lysate

PLA: Proximity ligation assay 
qPCR: Quantitative polymerase chain reaction

RT: Reverse transcriptase

siRNA: Small interfering RNA

STAT: Signal transducer and activator of transcription

SYK: Spleen tyrosine kinase

TGF: Transforming growth factor

TKI: Tyrosine kinase inhibitor

VCAM: Vascular cell adhesion protein

VLA-4: Very Late Antigen 4

Wnt: Wingless-related integration

$\beta 2$ integrin: $C D 18 /$ Integrin $\beta 2$

\section{Declarations}

Conflict of interest Disclosure: The authors declare no conflict of interest.

\section{Compliance with Ethical Standards-Yes}

Authors' Contributions Yogesh Kumar Verma conceptualized, wrote and edited the manuscript. Namrata Yadav, data analyzed, Subodh Kumar, drafting and edited the manuscript, Gurudutta Gangenahalli edited the manuscript.

Research Involving Human Participants and/or Animals: Not applicable.

Informed Consent: Not applicable.

Funding: Authors like to thanks Director, INMAS, Delhi for the encouragement and funding.

Research Involving Human Participants and/or Animals Not applicable.

Consent for publication Not applicable.

Funding Authors like to thanks Director, INMAS, Delhi for the encouragement and funding

Availability of data and materials: To analyze the effect of IR on CAMs in CML, the microarray data (GSE7505) of 8Gy irradiated K562 cells (K5628Gy) was extracted from $\mathrm{NCl} 60$ cell line data (https://dtp.cancer.gov/discovery_development/nci-60/). 
This was compared with microarray data of 8Gy exposed KG1a cells, whose "Minimum Information About a Microarray Experiment" (MIAME) compliant data were deposited in the GEO database (GSE73486) (http://www.ncbi.nlm.nih.gov/geo/).

\section{Acknowledgements}

Authors acknowledge Director INMAS for his continuous support. This work has been supported by the project no. INM/323, funded by Defence Research and Development Organisation. Authors thank Mrs. NamitaKalra, and Mr. Yogesh Raifor flow cytometry measurements and fluorescence microscopy respectively.

\section{References}

1. Mitchell, S., Ferdinand, Tumur, Batson, S., 2012. Treatments for chronic myeloid leukemia: a qualitative systematic review. J. Blood Med. 51. https://doi.org/10.2147/jbm.s33380

2. Hazlehurst, L.A., Damiano, J.S., Buyuksal, I., Pledger, W.J., Dalton, W.S., 2000. Adhesion to fibronectin via $\beta 1$ integrins regulates $p 27$ (kip1) levels and contributes to cell adhesion mediated drug resistance (CAM-DR). Oncogene 19, 4319-4327. https://doi.org/10.1038/sj.onc.1203782

3. Hehlgans, S., Haase, M., Cordes, N., 2007. Signalling via integrins: Implications for cell survival and anticancer strategies. Biochim. Biophys. Acta - Rev. Cancer 1775, 163-180. https://doi.org/10.1016/j.bbcan.2006.09.001

4. Watt, F.M., 2002. Role of integrins in regulating epidermal adhesion, growth and differentiation. EMBO J. 21, 3919-3926. https://doi.org/10.1093/emboj/cdf399

5. Zahir, N., Weaver, V.M., 2004. Death in the third dimension: Apoptosis regulation and tissue architecture. Curr. Opin. Genet. Dev. 14, 71-80. https://doi.org/10.1016/j.gde.2003.12.005

6. Hazlehurst, L.A., Damiano, J.S., Buyuksal, I., Pledger, W.J., Dalton, W.S., 2000. Adhesion to fibronectin via $\beta 1$ integrins regulates $\mathrm{p} 27$ (kip1) levels and contributes to cell adhesion mediated drug resistance (CAM-DR). Oncogene 19, 4319-4327. https://doi.org/10.1038/sj.onc.1203782

7. Hazlehurst, L.A., Landowski, T.H., Dalton, W.S., 2003. Role of the tumor microenvironment in mediating de novo resistance to drugs and physiological mediators of cell death. Oncogene 22, 7396-7402. https://doi.org/10.1038/sj.onc.1206943

8. Barry, M.A., Reynolds, J.E., Eastman, A., 1993. Etoposide-induced Apoptosis in Human HL-60 Cells Is Associated with Intracellular Acidification. Cancer Res. 53, 2349-2357.

9. Chodniewicz, D., Zhelev, D. V., 2003. Novel pathways of F-actin polymerization in the human neutrophil. Blood 102, 2251-2258. https://doi.org/10.1182/blood-2002-09-2936

10. Burridge, K., Fath, K., Kelly, T., Nuckolls, G., Turner, C., 1988. Focal adhesions: Transmembrane junctions between the extracellular matrix and the cytoskeleton. Annu. Rev. Cell Biol. 4, 487-525. https://doi.org/10.1146/annurev.cb.04.110188.002415 
11. Mostafavi, S., Ray, D., Warde-Farley, D., Grouios, C., Morris, Q., 2008. GeneMANIA: A real-time multiple association network integration algorithm for predicting gene function. Genome Biol. 9, 1-15. https://doi.org/10.1186/gb-2008-9-s1-s4

12. Livak, K.J., Schmittgen, T.D., 2001. Analysis of relative gene expression data using real-time quantitative PCR and the 2- $\Delta \mathrm{CT}$ method. Methods 25, 402-408. https://doi.org/10.1006/meth.2001.1262

13. Karimiani, E.G., Marriage, F., Merritt, A.J., Burthem, J., Byers, R.J., Day, P.J.R., 2014. Single-cell analysis of K562 cells: An imatinib-resistant subpopulation is adherent and has upregulated expression of BCR-ABL mRNA and protein. Exp. Hematol. 42, 183-191.e5.

https://doi.org/10.1016/j.exphem.2013.11.006

14. Greenfield, K., Mokhtari, S., Haug, M., Porada, C.D. and Almeida-Porada, G., 2012. Identification and Phenotypic Characterization of a Subpopulation of Acute Myelogenous Leukemia (AML) Cells with Increased Plastic Adherence. Blood 2012; 120 (21): 2556.

https://doi.org/10.1182/blood.V120.21.2556.2556

15. Hazlehurst, L.A., Damiano, J.S., Buyuksal, I., Pledger, W.J., Dalton, W.S., 2000. Adhesion to fibronectin via $\beta 1$ integrins regulates $\mathrm{p} 27$ (kip1) levels and contributes to cell adhesion mediated drug resistance (CAM-DR). Oncogene 19, 4319-4327. https://doi.org/10.1038/sj.onc.1203782

16. Nurmi, S.M., Autero, M., Raunio, A.K., Gahmberg, C.G. and Fagerholm, S.C., 2007. Phosphorylation of the LFA-1 integrin $\beta 2$-chain on Thr-758 leads to adhesion, Rac-1/Cdc42 activation, and stimulation of CD69 expression in human T cells. Journal of Biological Chemistry, 282(2), pp.968975.https://doi.org/10.1074/jbc.M608524200

17. Watcharasit, P., Bijur, G. N., Song, L., Zhu, J., Chen, X., \&Jope, R. S. (2003). Glycogen synthase kinase3beta (GSK3beta) binds to and promotes the actions of p53. The Journal of biological chemistry, 278(49), 48872-48879. https://doi.org/10.1074/jbc.M305870200

18. Di Maggio, F.M., Minafra, L., Forte, G.I., Cammarata, F.P., Lio, D., Messa, C., Gilardi, M.C. and Bravatà, V., 2015. Portrait of inflammatory response to ionizing radiation treatment. Journal of inflammation, 12(1), pp.1-11.

19. Yi, M. and Ruoslahti, E., 2001. A fibronectin fragment inhibits tumor growth, angiogenesis, and metastasis. Proceedings of the National Academy of Sciences, 98(2), pp.620-624.doi: 10.1073/pnas.98.2.620.

20. Oellerich, T., Oellerich, M.F., Engelke, M., Münch, S., Mohr, S., Nimz, M., Hsiao, H.H., Corso, J., Zhang, J., Bohnenberger, H. and Berg, T., 2013. $\beta 2$ integrin-derived signals induce cell survival and proliferation of AML blasts by activating a Syk/STAT signaling axis. Blood, The Journal of the American Society of Hematology, 121(19), pp.3889-3899.doi: 10.1182/blood-2012-09-457887

21. Pecquet, S., Bovetto, L., Maynard, F. and Fritsché, R., 2000. Peptides obtained by tryptic hydrolysis of bovine $\beta$-lactoglobulin induce specific oral tolerance in mice. Journal of Allergy and Clinical Immunology, 105(3), pp.514-521.doi: 10.1067/mai.2000.111147 
22. Koopman, G., Keehnen, R.M., Lindhout, E., Newman, W., Shimizu, Y., Van Seventer, G.A., De Groot, C. and Pals, S.T., 1994. Adhesion through the LFA-1 (CD11a/CD18)-ICAM-1 (CD54) and the VLA-4 (CD49d)-VCAM-1 (CD106) pathways prevents apoptosis of germinal center B cells. The Journal of Immunology, 152(8), pp.3760-3767.

23. Koopman, G., Keehnen, R.M., Lindhout, E., Newman, W., Shimizu, Y., Van Seventer, G.A., De Groot, C. and Pals, S.T., 1994. Adhesion through the LFA-1 (CD11a/CD18)-ICAM-1 (CD54) and the VLA-4 (CD49d)-VCAM-1 (CD106) pathways prevents apoptosis of germinal center B cells. The Journal of Immunology, 152(8), pp.3760-3767.

24. Wilhelmsen, K., Litjens, S.H. and Sonnenberg, A., 2006. Multiple functions of the integrin a6 $\beta 4$ in epidermal homeostasis and tumorigenesis. Molecular and cellular biology, 26(8), pp.28772886.https://doi.org/10.1128/MCB.26.8.2877-2886.2006

25. Yoshida, T., Kimura, E., Koike, S., Nojima, J., Futai, E., Sasagawa, N., Watanabe, Y. and Ishiura, S., 2011. Transgenic rice expressing amyloid $\beta$-peptide for oral immunization. International journal of biological sciences, 7(3), p.301. doi:10.7150/ijbs.7.301

26. Ross, D.D., Karp, J.E., Chen, T.T. and Doyle, L.A., 2000. Expression of breast cancer resistance protein in blast cells from patients with acute leukemia: Presented in part at the Fortieth Annual Meeting of the American Society of Hematology, Miami Beach, FL, December 4-8, 1998. Blood, The Journal of the American Society of Hematology, 96(1), pp.365-368.

27. Helbig, G., Christopherson II, K.W., Bhat-Nakshatri, P., Kumar, S., Kishimoto, H., Miller, K.D., Broxmeyer, H.E. and Nakshatri, H., 2003. NF-K B promotes breast cancer cell migration and metastasis by inducing the expression of the chemokine receptor CXCR4. Journal of biological chemistry, 278(24), pp.21631-21638.

28. Tang, W., Lu, Y., Tian, Q.Y., Zhang, Y., Guo, F.J., Liu, G.Y., Syed, N.M., Lai, Y., Lin, E.A., Kong, L. and Su, J., 2011. The growth factor progranulin binds to TNF receptors and is therapeutic against inflammatory arthritis in mice. Science, 332(6028), pp.478-484.

29. Zhang, Y.E., 2009. Non-Smad pathways in TGF- $\beta$ signaling. Cell Res. 19, 128-139. https://doi.org/10.1038/cr.2008.328

30. MacDonald, B.T., Tamai, K. and He, X., 2009. Wnt/ $\beta$-catenin signaling: components, mechanisms, and diseases. Developmental cell, 17(1), pp.9-26.

31. Watson, R.L., Spalding, A.C., Zielske, S.P., Morgan, M., Kim, A.C., Bommer, G.T., Eldar-Finkelman, H., Giordano, T., Fearon, E.R., Hammer, G.D., Lawrence, T.S., Ben-Josef, E., 2010. Gsk3 $\beta$ and $\beta$-catenin modulate radiation cytotoxicity in pancreatic cancer. Neoplasia 12, 357-365. https://doi.org/10.1593/neo.92112

32. Landberg, N., Hansen, N., Askmyr, M., Ågerstam, H., Lassen, C., Rissler, M., Hjorth-Hansen, H., Mustjoki, S., Järås, M., Richter, J. and Fioretos, T., 2016. IL1RAP expression as a measure of leukemic stem cell burden at diagnosis of chronic myeloid leukemia predicts therapy outcome. Leukemia, $30(1)$, pp. $255-258$. 
33. Puissant, A., Dufies, M., Fenouille, N., Ben Sahra, I., Jacquel, A., Robert, G., Cluzeau, T., Deckert, M., Tichet, M., Chéli, Y., Cassuto, J.P., Raynaud, S., Legros, L., Pasquet, J.M., Mahon, F.X., Luciano, F., Auberger, P., 2012. Imatinib triggers mesenchymal-like conversion of CML cells associated with increased aggressiveness. J. Mol. Cell Biol. 4, 207-220. https://doi.org/10.1093/jmcb/mjs010

34. Gigante, M., Gesualdo, L., Ranieri, E., 2012. TGF-Beta: a Master Switch in Tumor Immunity. Curr. Pharm. Des. 18, 4126-4134. https://doi.org/10.2174/138161212802430378

35. Burridge, K., Fath, K., Kelly, T., Nuckolls, G., Turner, C., 1988. Focal adhesions: Transmembrane junctions between the extracellular matrix and the cytoskeleton. Annu. Rev. Cell Biol. 4, 487-525. https://doi.org/10.1146/annurev.cb.04.110188.002415

36. Hehlgans, S., Haase, M., Cordes, N., 2007. Signalling via integrins: Implications for cell survival and anticancer strategies. Biochim. Biophys. Acta - Rev. Cancer 1775, 163-180.

https://doi.org/10.1016/j.bbcan.2006.09.001

37. Cordes, N., Hansmeier, B., Beinke, C., Meineke, V. and Van Beuningen, D., 2003. Irradiation differentially affects substratum-dependent survival, adhesion, and invasion of glioblastoma cell lines. British journal of cancer, 89(11), pp.2122-2132. doi:10.1038/sj.bjc.6601429

38. Sethi, T., Rintoul, R.C., Moore, S.M., MacKinnon, A.C., Salter, D., Choo, C., Chilvers, E.R., Dransfield, I., Donnelly, S.C., Strieter, R. and Haslett, C., 1999. Extracellular matrix proteins protect small cell lung cancer cells against apoptosis: a mechanism for small cell lung cancer growth and drug resistance in vivo. Nature medicine, 5(6), pp.662-668.doi: 10.1038/9511

39. Plate, J.M.D., Long, B.W. and Kelkar, S.B., 2000. Role of $\beta 2$ integrins in the prevention of apoptosis induction in chronic lymphocytic leukemia B cells. Leukemia, 14(1), pp.34-39.

40. Zahalka, M.A., Okon, E. and Naor, D., 1993. Blocking lymphoma invasiveness with a monoclonal antibody directed against the beta-chain of the leukocyte adhesion molecule (CD18). The Journal of Immunology, 150(10), pp.4466-4477.

41. Albelda, S.M. and Buck, C.A., 1990. Integrins and other cell adhesion molecules. The FASEB Journal, 4(11), pp.2868-2880.

42. Shoemaker, R.H., 2006. The NCl60 human tumour cell line anticancer drug screen. Nature Reviews Cancer, 6(10), pp.813-823.

\section{Tables}

Table1 Upregulated genes' ontologies at 8Gy 
KG1a

Cell junction assembly

$T$ cell costimulation

Astrocyte development

Collagen catabolic process

Calcium independent cell-cell adhesion
K562

Positive regulation of smooth muscle cell proliferation

Heterophilic cell-cell adhesion

Response to organophospahate

Cell junction assembly

Homotypic cell-cell adhesion

Axon regeneration

Extracellular matrix organization

Cell-cell adhesion

Cell-substrate junction assembly

Regulation of immunoglobulin mediated immune response

Face development

Positive regulation of muscle cell development

\section{Downregulated genes' ontologies at 8Gy}

Heterotypic cell-cell adhesion

Cell substrate junction assembly

Adherens junction organization

Table 2. Common adhesion related genes up/downregulated in KG1a and K562, after IR exposure. 


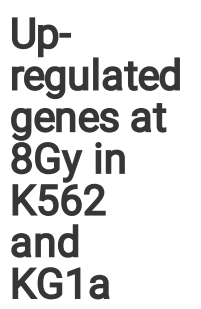

Common Function

ACTN2 Actinin alpha 2 gene is F-actin cross-linking protein which is thought to anchor actin to a variety of intracellular structures. This is a bundling protein.

CAV1 It acts as a scaffolding protein within caveolar membranes. Interacts directly with Gprotein alpha subunits and can functionally regulate their activity. It is involved in the costimulatory signal essential for T-cell receptor (TCR)-mediated T-cell activation. Its binding to DPP4 induces T-cell proliferation and NF-kappa-B activation in a T-cell receptor/CD3-dependent manner. It recruits CTNNB1 to caveolar membranes and may regulate CTNNB1-mediated signaling through the Wnt pathway.

VWF Von Willebrand factor is important in the maintenance of hemostasis, it promotes adhesion of platelets to the sites of vascular injury by forming a molecular bridge between sub-endothelial collagen matrix and platelet-surface receptor complex GPIb-IX-V. It also acts as a chaperone for coagulation factor VIII, delivering it to the site of injury, stabilizing its heterodimeric structure and protecting it from premature clearance from plasma.

CDH15 Cadherins \{cadherin 15, type 1, M-cadherin (myotubule)\} are calcium dependent cell adhesion proteins. They preferentially interact with themselves in a homophilic manner in connecting cells; cadherins may thus contribute to the sorting of heterogeneous cell types. M-cadherin is part of the myogenesis program and may provide a trigger for terminal muscle differentiation.

JAM2 This gene belongs to the immunoglobulin superfamily, and the junctional adhesion molecule (JAM) family. The protein encoded by this gene is a type I membrane protein that is localized at the tight junctions of both epithelial and endothelial cells. It acts as an adhesive ligand for interacting with a variety of immune cell types, and may play a role in lymphocyte homing to secondary lymphoid organs.

NCAM2 This gene belongs to the immunoglobulin superfamily. It is a type I membrane protein and may function in selective fasciculation and zone-to-zone projection of the primary olfactory axons.

L1CAM L1 cell adhesion molecule plays an important role in the development of the nervous system. Involved in neuron-neuron adhesion, neurite fasciculation, outgrowth of neurites, etc. It binds to axonin on neurons.

CD28 It is involved in T-cell activation, the induction of cell proliferation and cytokine production and promotion of T-cell survival. 
genes at

$8 \mathrm{~Gy}$ in

K562

and

KG1a

cells

CD2

It interacts with lymphocyte function-associated antigen (LFA-3) and CD48/BCM1 to mediate adhesion between T-cells and other cell types. CD2 is implicated in the triggering of T- cells.

Figures 

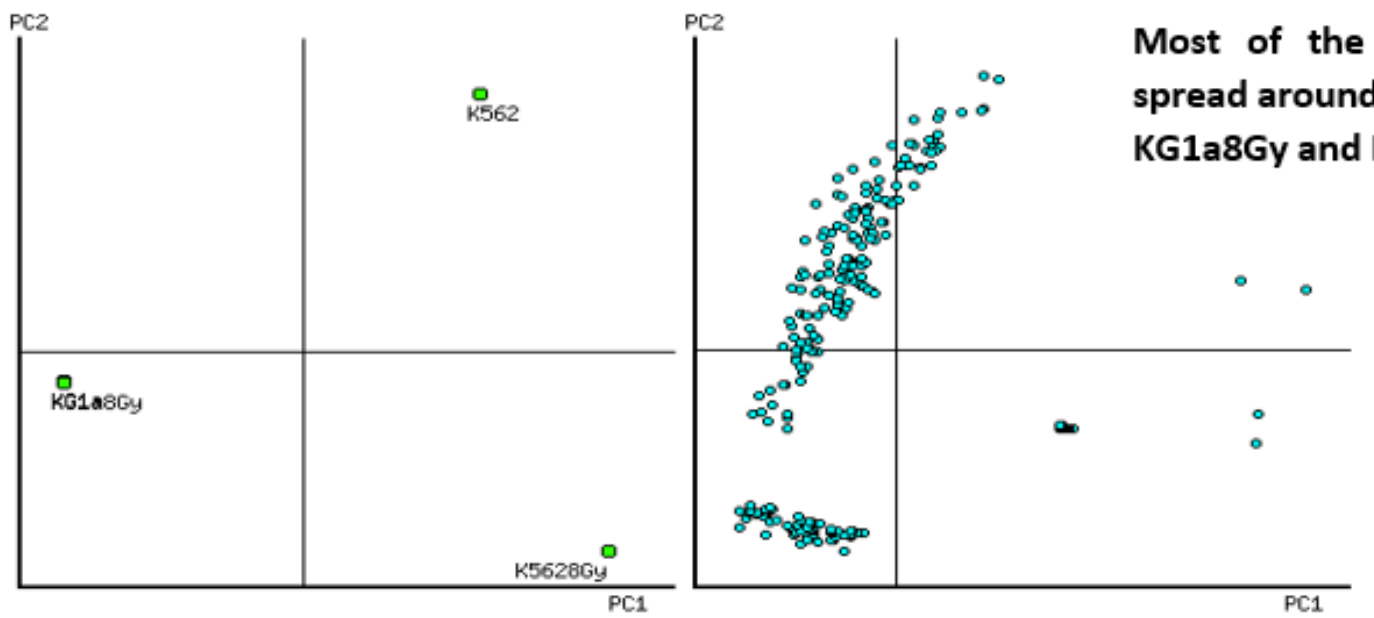

(a)

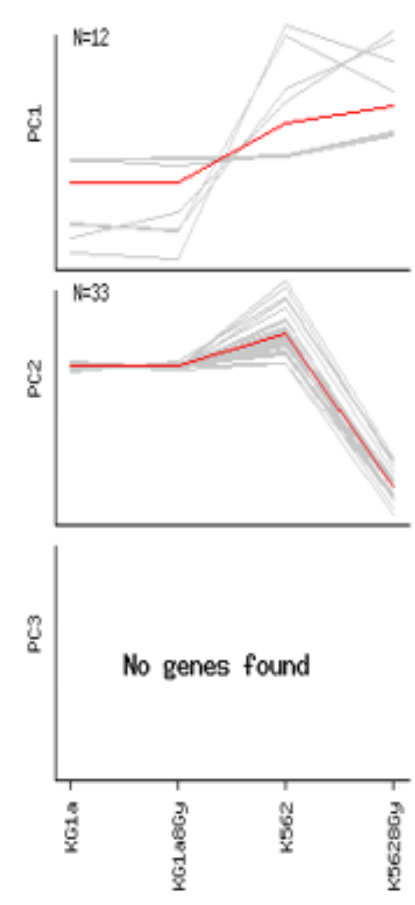

(b)

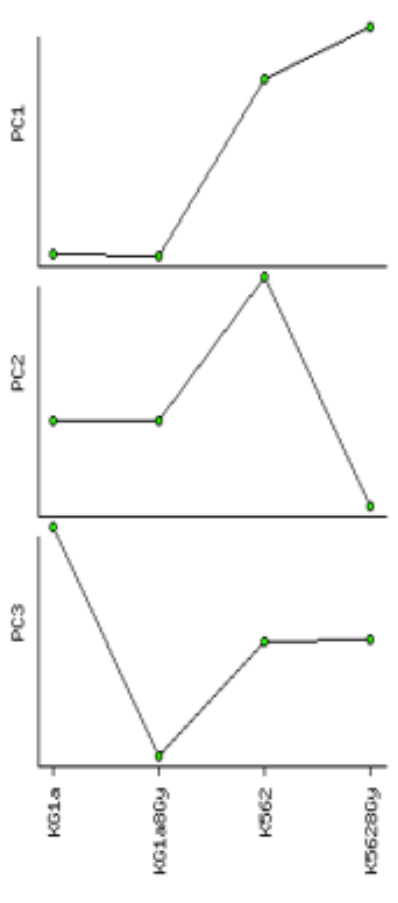

(c)

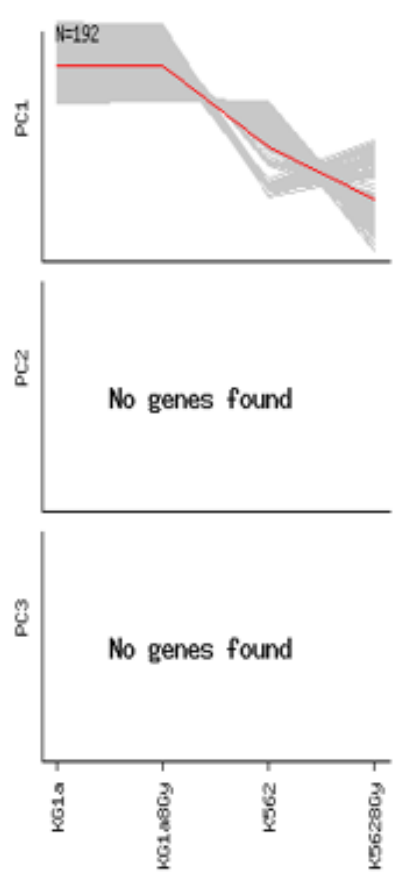

(d)

\section{Figure 1}

(a) PCA bi-plot of the KG1a and K562 genes expression showing strong correlation between KG1a and KG1a8Gy samples. (b) PC-based clustering of genes: cluster of genes correlated with each PC. Correlation threshold $=0.7$; Fold change threshold $=2$. (c) Positive correlation. (d) Negative correlation . 


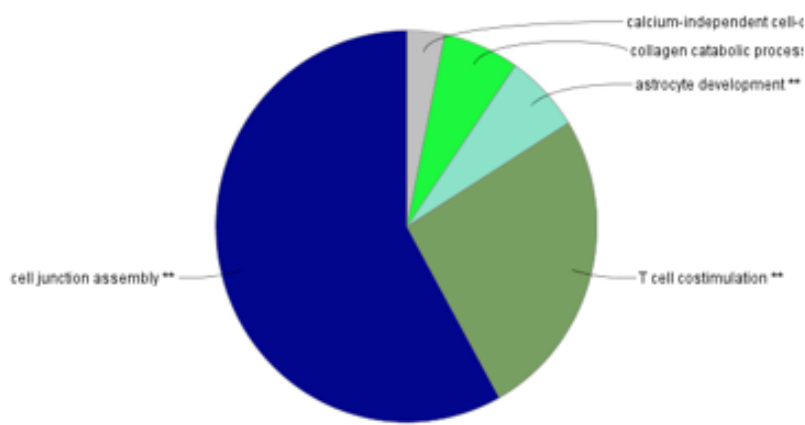

ClueGO network of KGla8Gy (Upregulated genes' ontology)

(a)

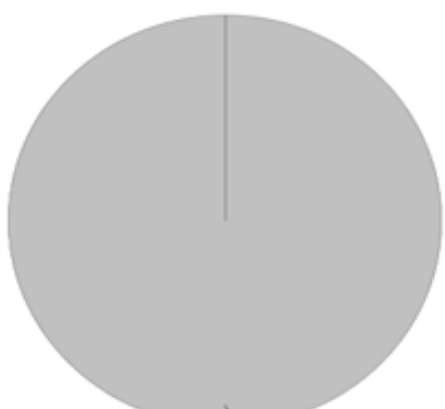

ClueGO network of KG1a8Gyyrotopic cell-cell adhesion (Downregulated genes' ontology)

(c)

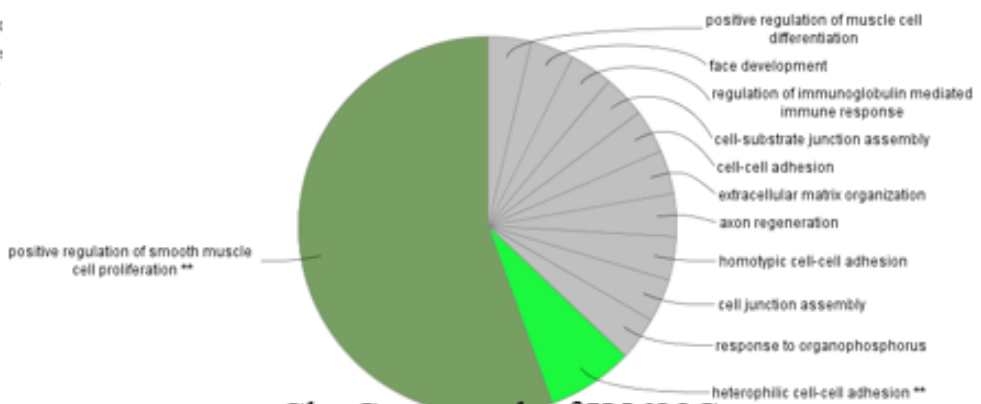

ClueGo network of K5628Gy

(Upregulated genes' ontology)

(b)

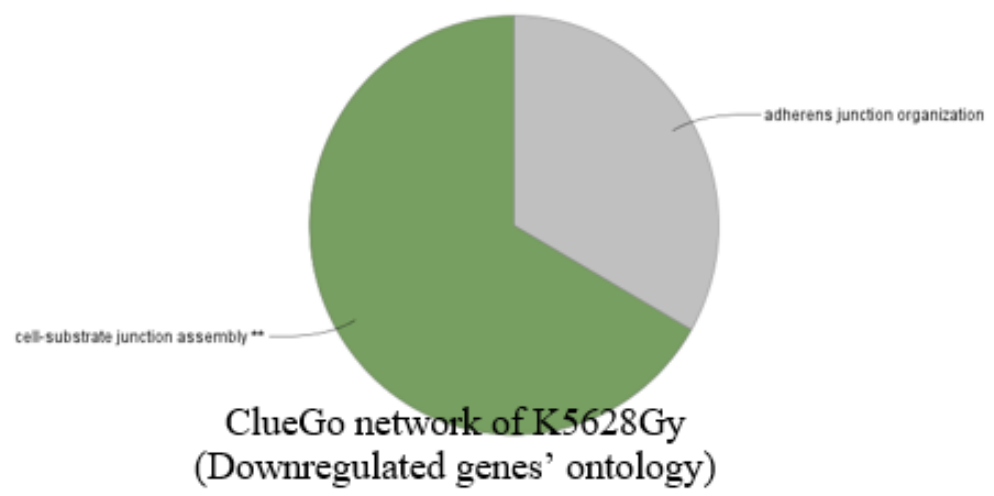

(d)

\section{Figure 2}

(a-d) Functional groups including specific terms for upregulated and downregulated genes. 


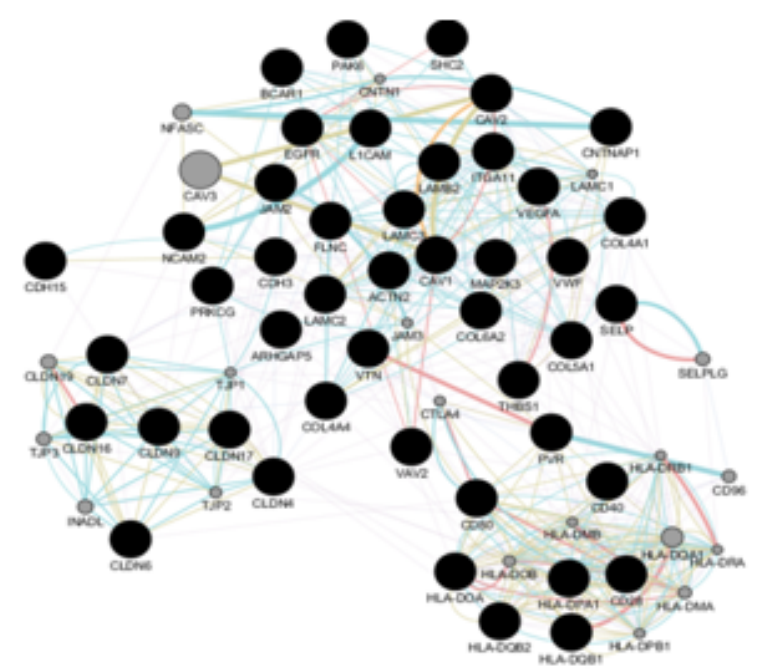

(a)

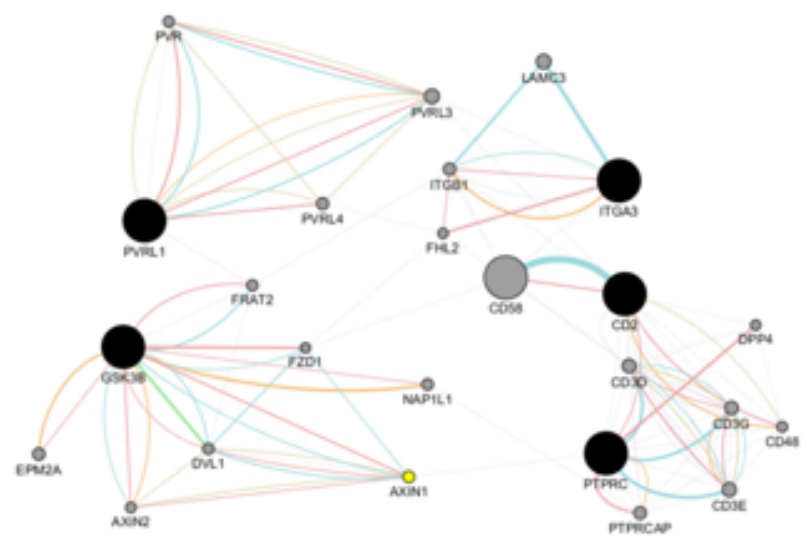

(c)
- $\square$ Physical Interactions

- घco-expression

- $\square$ Predicted

- DCo-localization

- DGenetic Interactions

- QPathway

- D shared protein domains

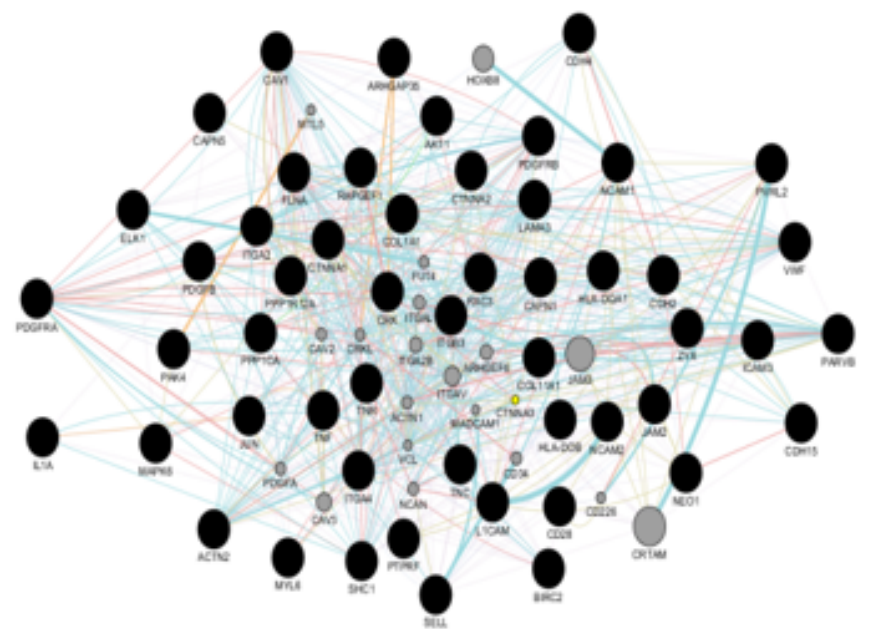

(b)

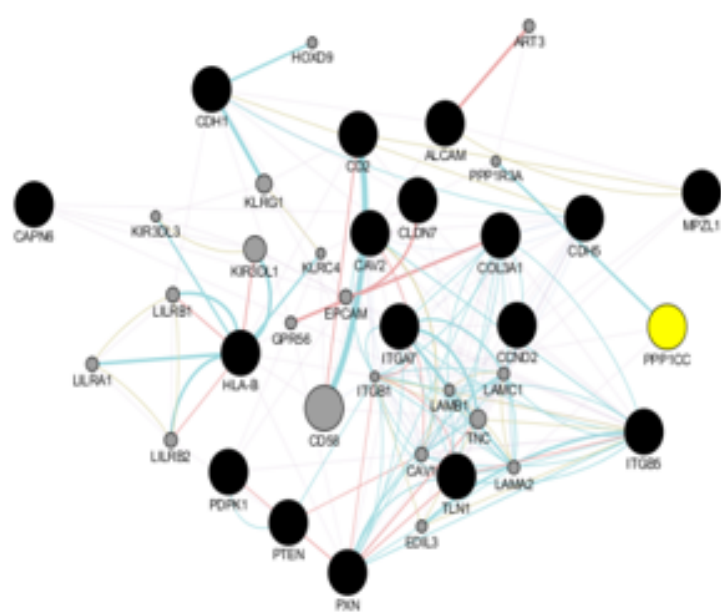

(d)

\section{Figure 3}

Interactions among a set of cell adhesion genes at 8Gy which were provided as query (black nodes) in Cytoscape GeneMANIA app and number of additional cell adhesion genes those predicted to be related (grey nodes). (a) KG1a8Gy upregulated genes interactions network. (b) K5628Gy upregulated genes interaction network. (c) KG1a8Gy downregulated genes interaction network. (d) K5628Gy downregulated genes interaction network. 

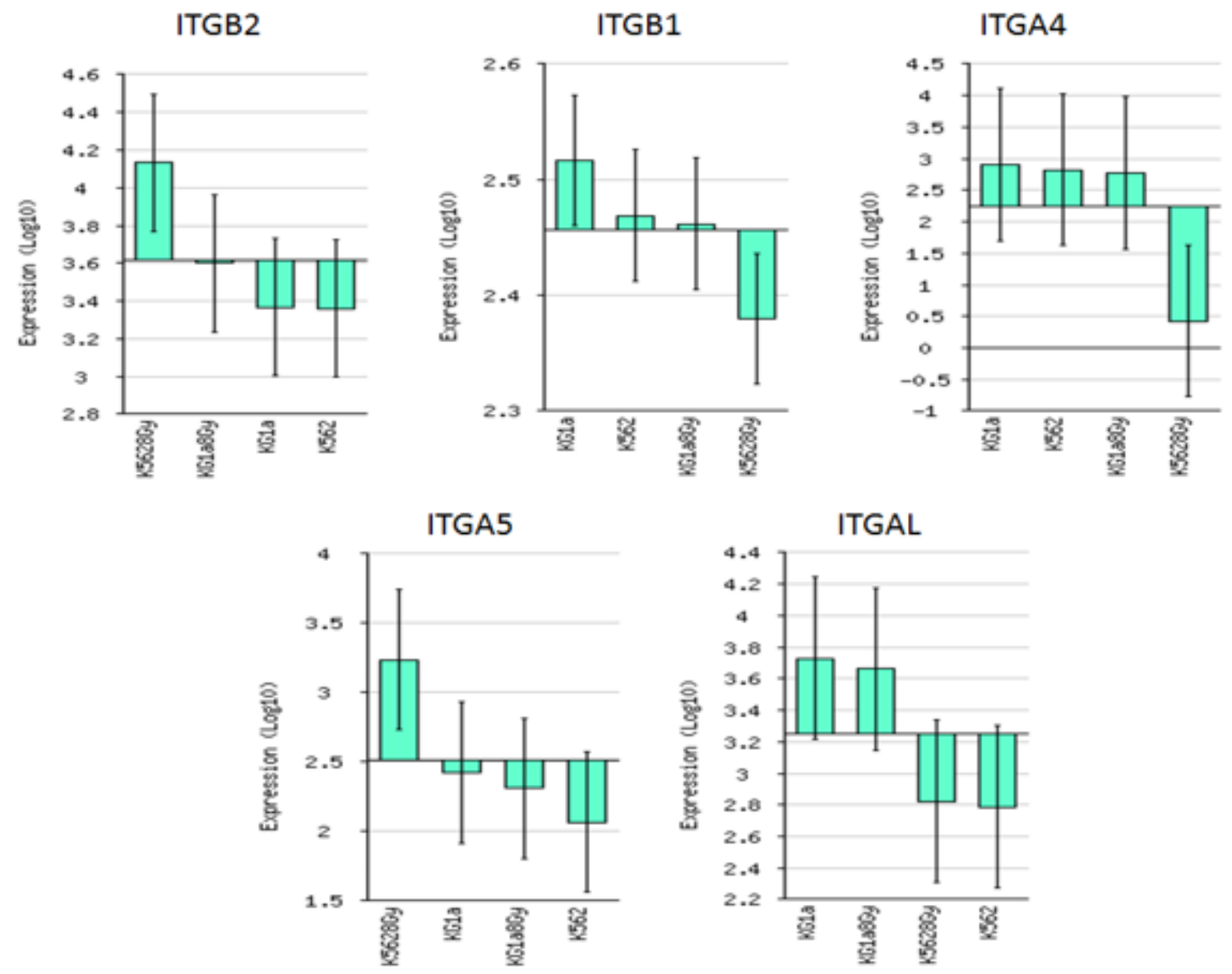

Figure 4

Comparison of integrins expression among KG1a, K562, KG1a8Gy and K5628Gy. Integrin $\beta 2$ displays maximum expression in K562 cells exposed to 8Gy. 


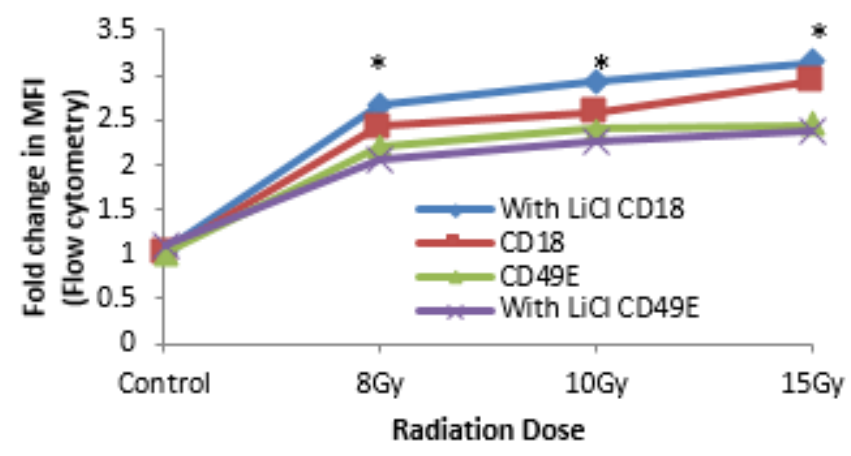

(A)

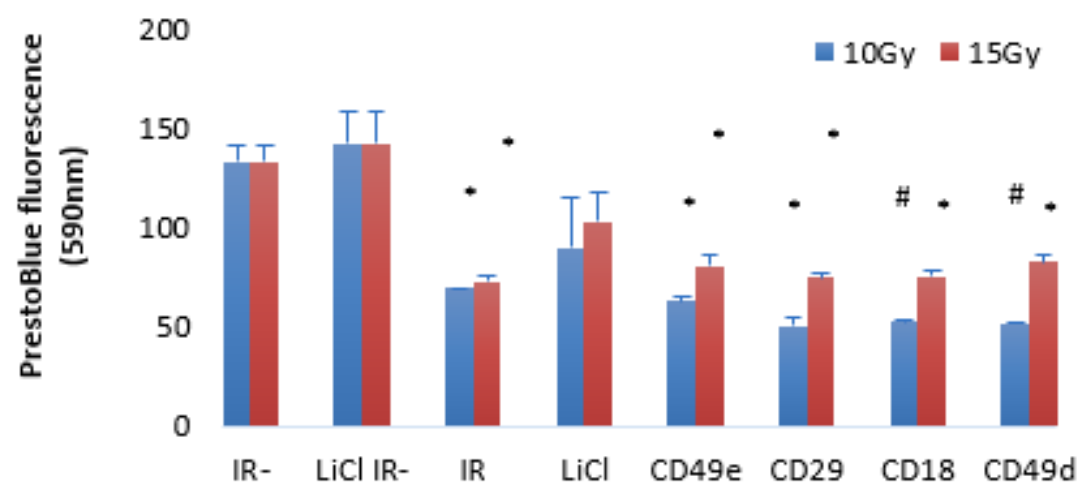

(B)

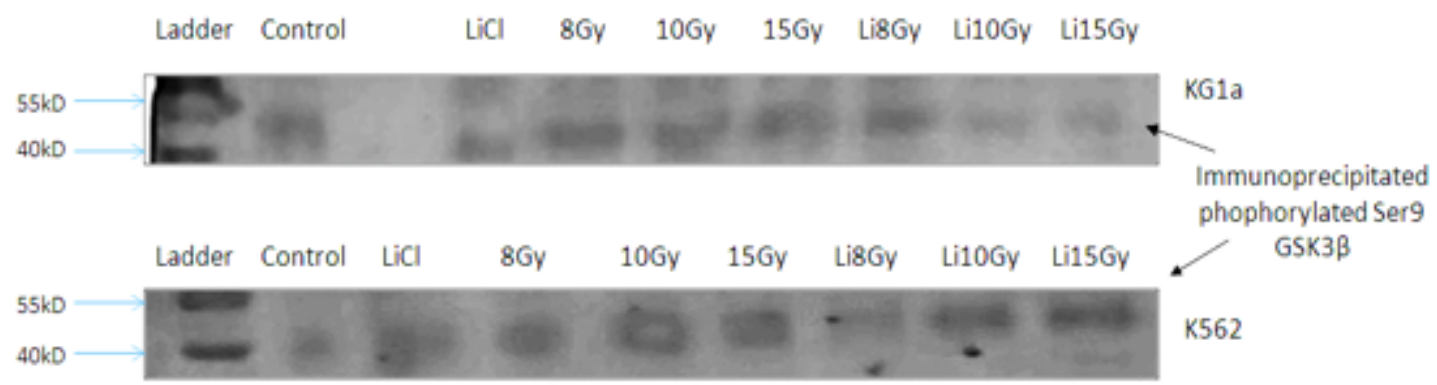

(C)

\section{Figure 5}

(a) CD18 expresses at significantly higher level as compared to CD49E in the presence of LiCl and IR exposure, beckoning its role in CAM-RR. The exclusive treatment of either $\mathrm{LiCl}$ or IR is not enough, whereas their synergism considerably increased CD18 expression at 8, 10 and $15 \mathrm{~Gy}$. ${ }^{*} \mathrm{p} \leq 0.05$; MFI: Mean Fluorescence Intensity was measured in FACS Aria II flow cytometer, BD, USA. (b) The blocking of CD18 and CD49d receptors with their respective monoclonal antibody maximally decreases cell attachment consequent to $\mathrm{LiCl}$ and IR exposure as compared to other integrins receptor. IR-; unirradiated 
cells. ${ }^{\star} p \leq 0.05 ; \# p \leq 0.005$. (c) The combined LiCl and IR treatment leads to the higher detection of the phosphorylated form of GSk3ß at serine 9.

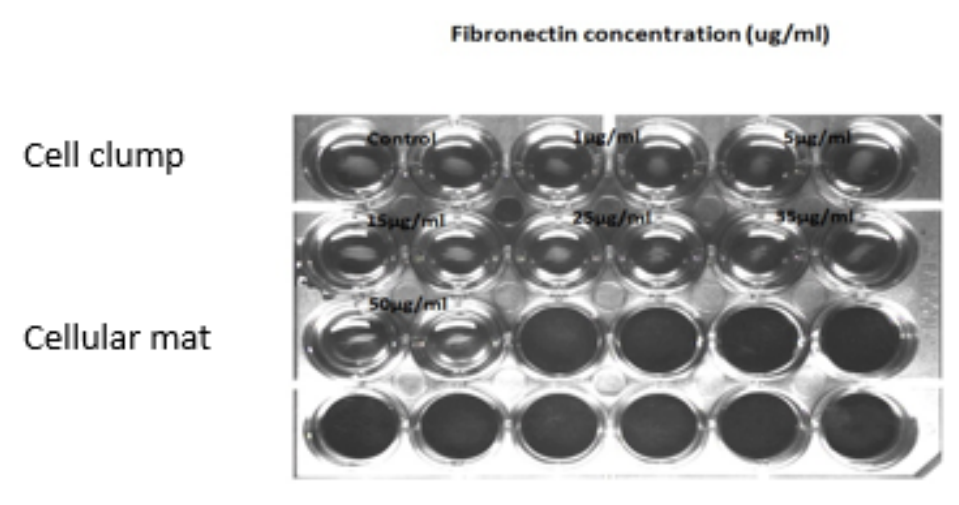

(a)

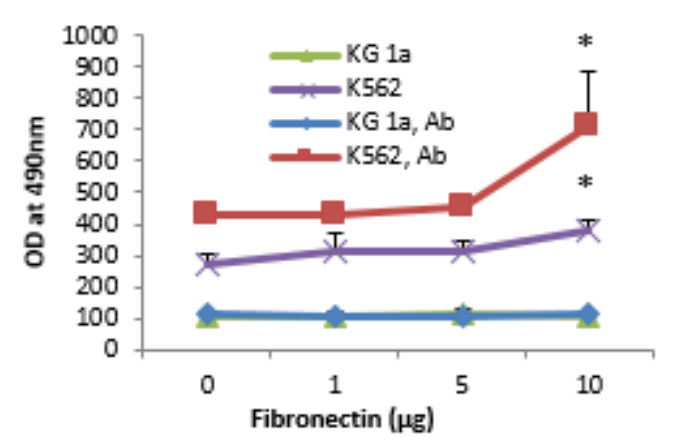

(b)

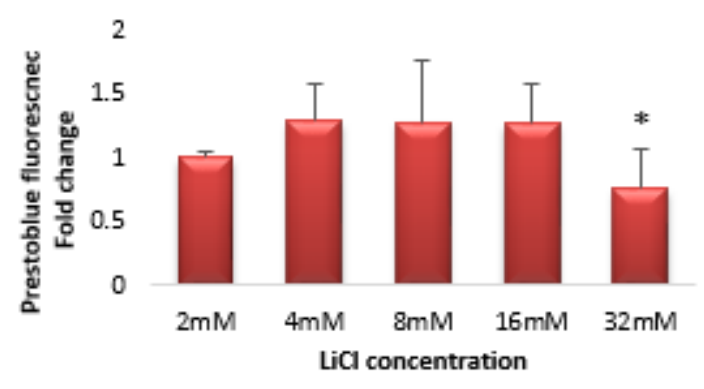

(c)

\section{Figure 6}

(a) Fibronectin decreases cell-cell contact and promotes adhesion to the supporting matrix, leading to mat formation at $50 \mu \mathrm{g} / \mathrm{ml}$. (b) $\mathrm{K} 562$ cells adhere more to fibronectin coated plates and adhesion increased proportionately with the concentration of fibronectin in coated wells. The maximum adhesion was observed in case of wells coated with $10 \mu \mathrm{g}$ fibronectin. KG-1 a cells although bind to fibronectin coated wells but were not affected by fibronectin concentration. This adhesion was not effected in the presence of CD49e blocking antibody (Ab) in KG1a cells.(c) Cell adhesion was maximum to growth surface in the presence of $4 \mathrm{mM} \mathrm{LiCl}$ and minimum at $32 \mathrm{mM}$. ( ${ }^{*} \mathrm{p}$-value $\left.\leq 0.05\right)$ 


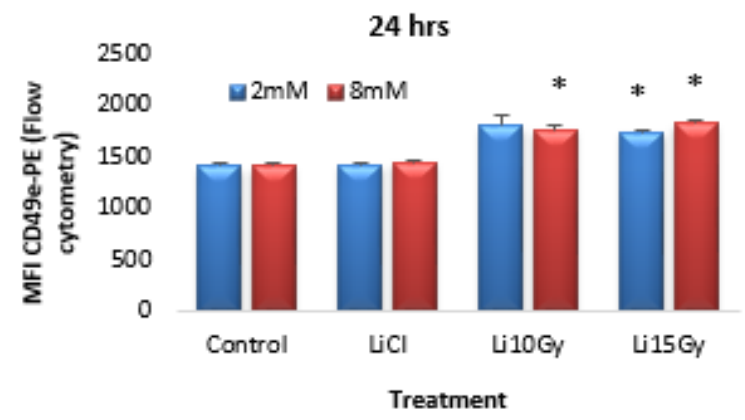

(a)

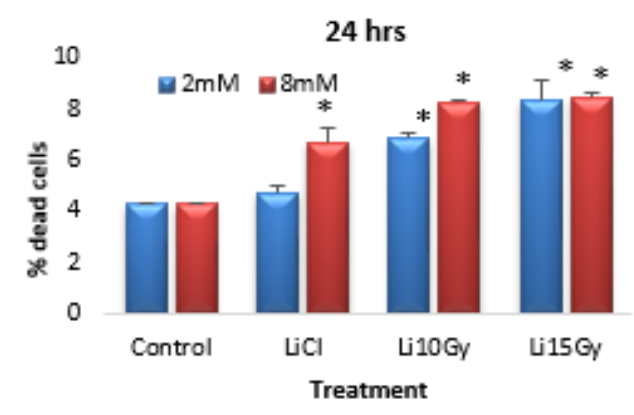

(c)

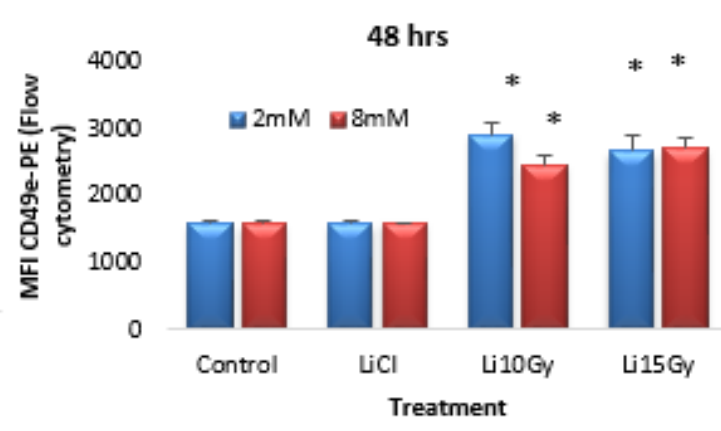

(b)

48 hrs

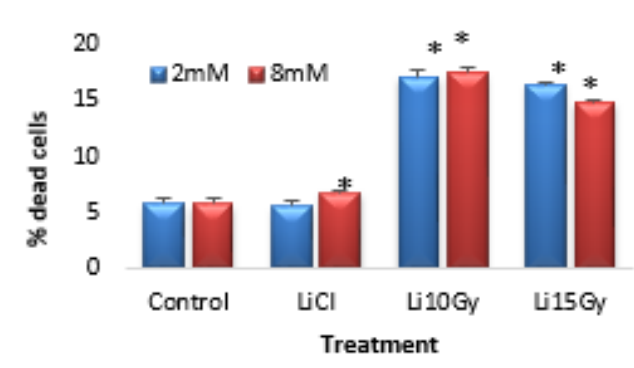

(d)

Bright field (10X)

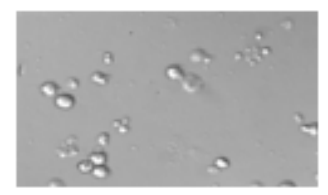

Green fluorescence

(10X)
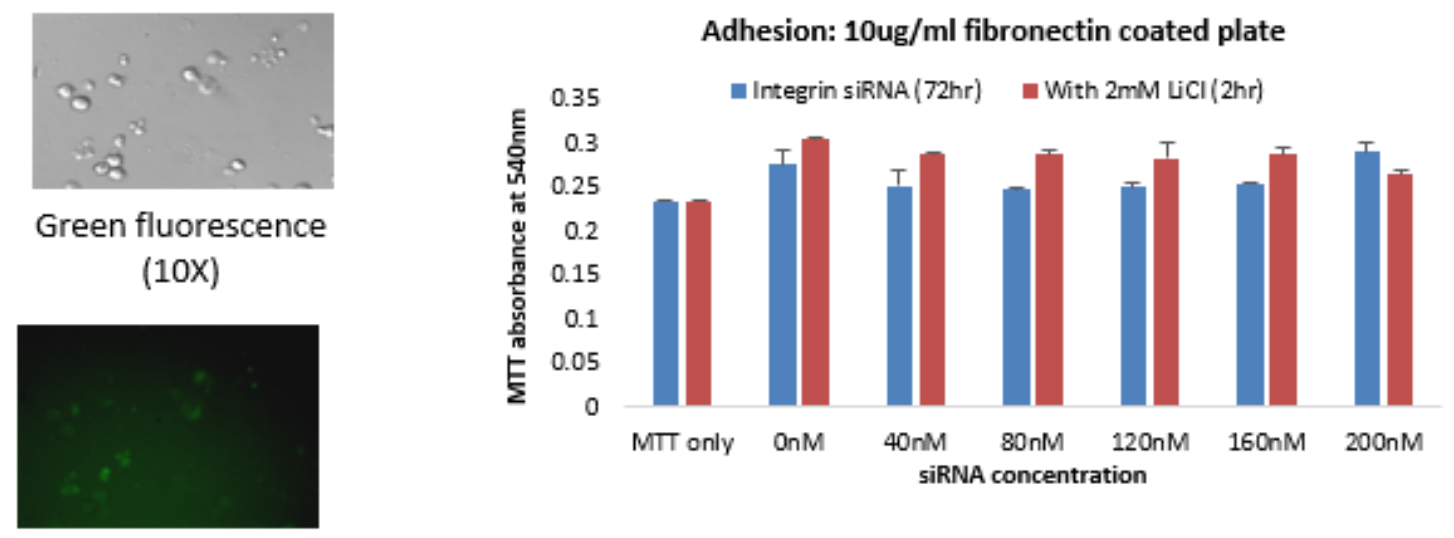

(e)

(f)

\section{Figure 7}

(a, b) LiCl does not impinge upon integrin a5 expression, while simultaneous IR exposure significantly influences CD49e expression on cell surface ( $\left.{ }^{*} \mathrm{p} \leq 0.05\right)$. (c, d) Both $\mathrm{LiCl}(8 \mathrm{mM})$ and radiation causes significant cell death whereas $2 \mathrm{mM} \mathrm{LiCl}$ exposure was safe up to $48 \mathrm{hr}$ ( $\left.{ }^{*} \mathrm{p} \leq 0.05\right)$. (e) FITC labeled control siRNA (\#sc-36869, Santa Cruz, USA) transfected in K562 cells (f) Not significant decrease in cell adhesion 
on fibronectin coated plate was seen in K562 cells transfected with CD49e siRNA at 72hr. MFI = Mean Fluorescence Intensity.

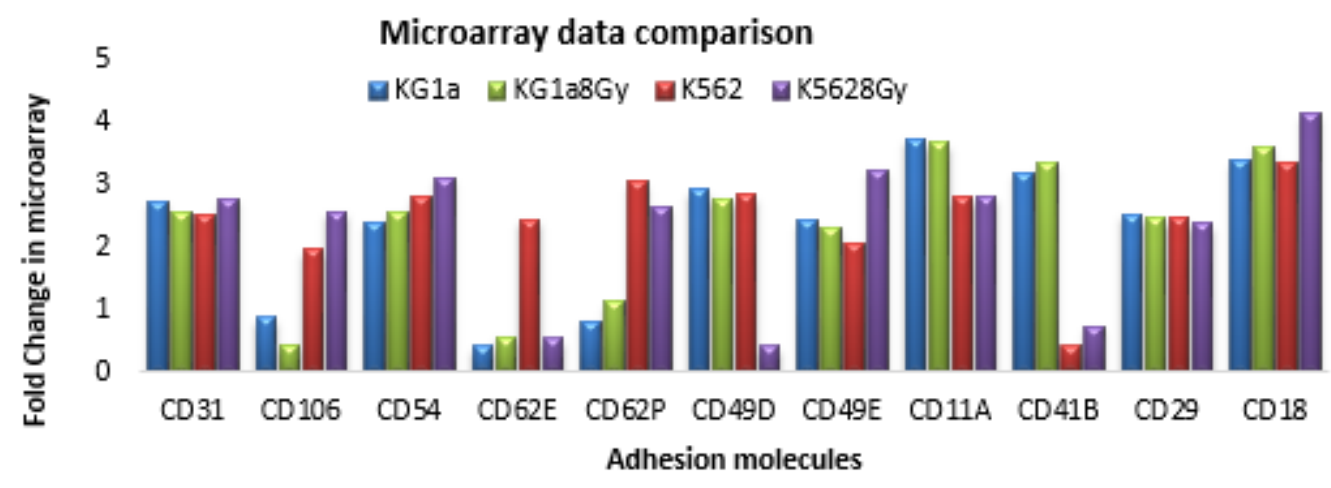

(a)

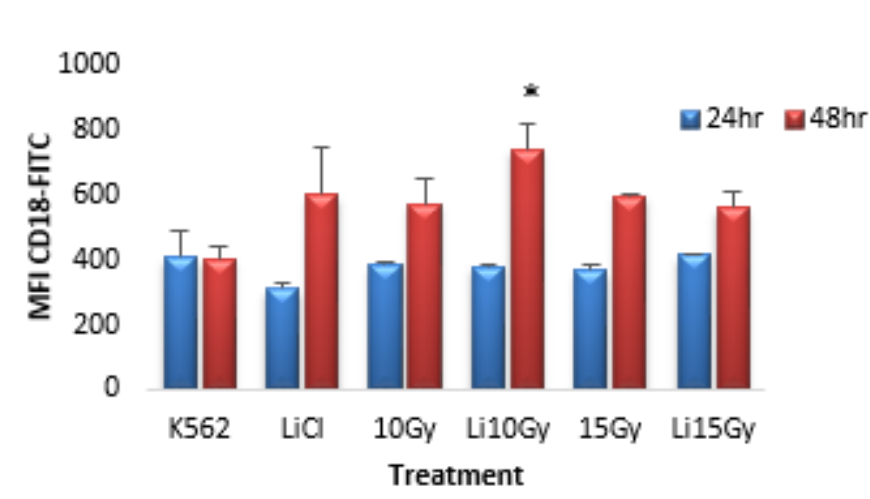

(b)

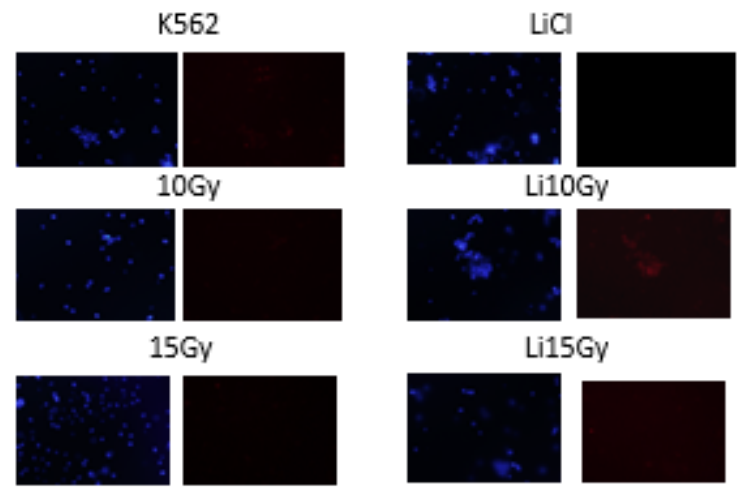

(c)

Figure 8

(a) ComparisonofKG1a and K562 microarray data. Highest expression in terms of fold change was observed for CD18 in K5628Gy sample. (b) The combined effect of radiation and LiCl in inducing CD18 expression was reported only after $48 \mathrm{hr}$ of incubation. At $24 \mathrm{hr}$, no change in expression was seen. (c) Immunostained K562 cells showing expression of CD18 (green fluorescence) compared to control (blue fluorescence of DAPI). 


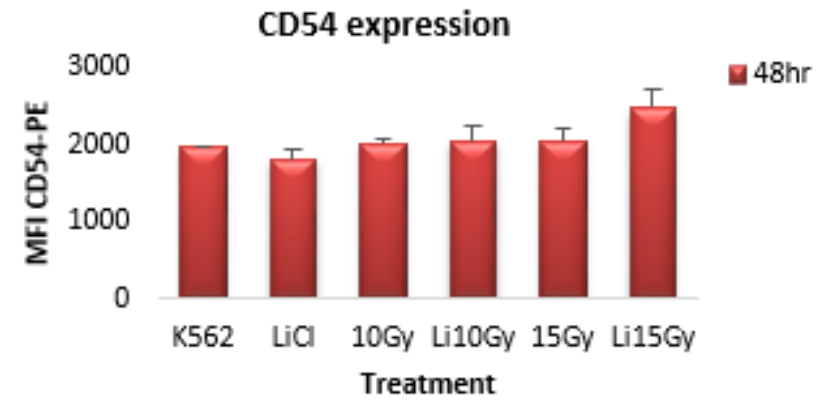

(a)

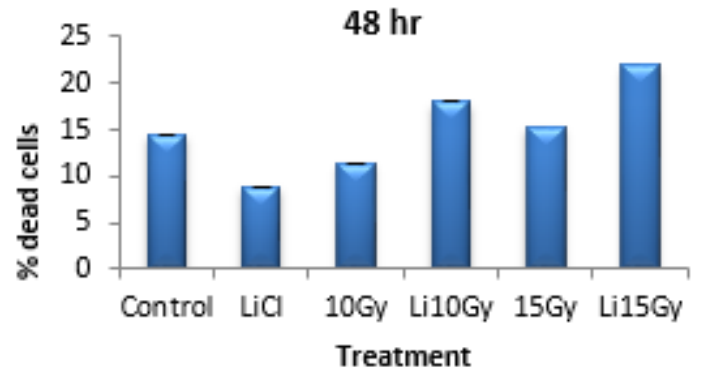

(b)

\section{Figure 9}

(a) K562 cells do not show significant increase in CD54 expression upon LiCl treatment and IR exposure.

(b) No difference in cell death was seen. Similarly, the CD41b antibody blocked cells were plated to adhere on fibronectin coated wells. No marked difference in adhesion of cells was observed even upon $50 \mu \mathrm{g}$ of fibronectin coating (data not shown).

TWM: K562

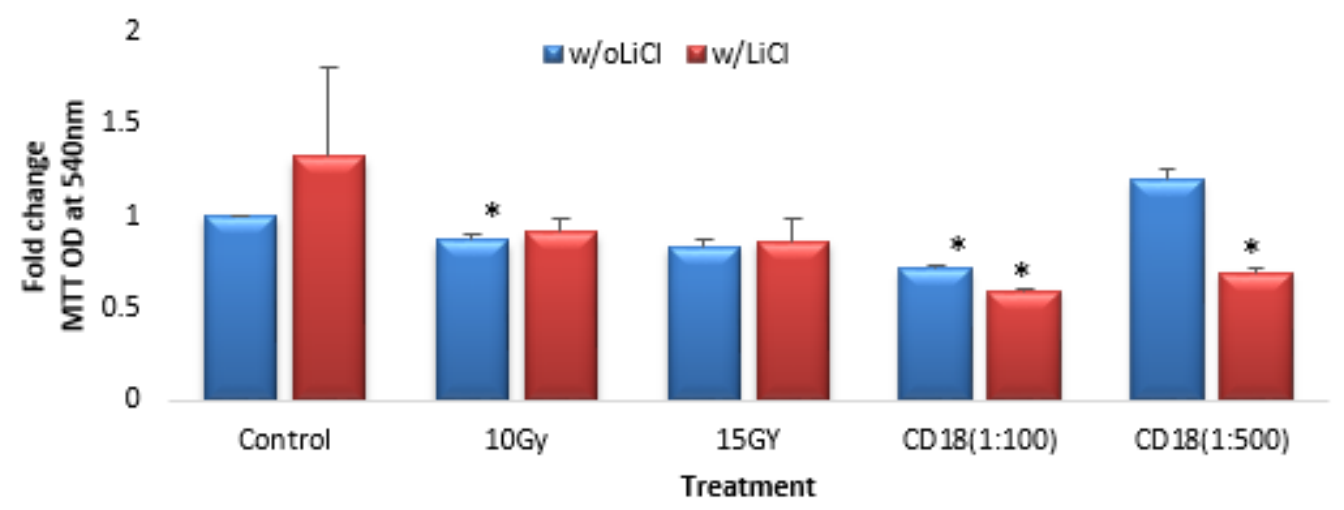

(a)

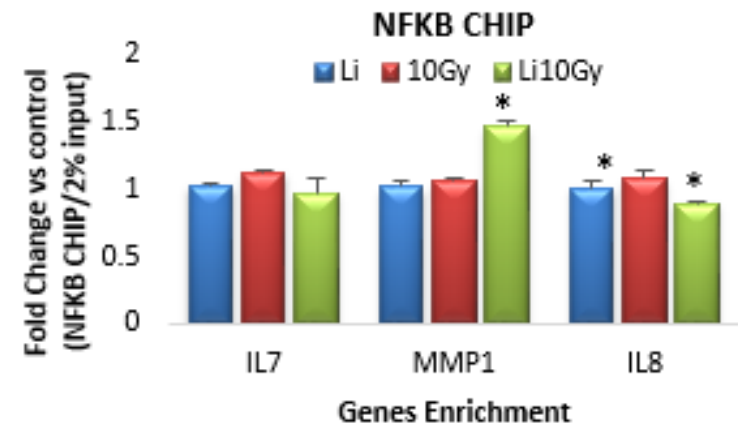

(b)

Figure 10 
(a) IR exposed or CD18 antibody (1:100 or 1:500 diluted in PBS) blocked cell migration was significantly decreased against control. Pre-exposure of $\mathrm{LiCl}$ to irradiated cell did not improve cell migration, making radiotherapy as an anti-metastatic measure paradoxically with CAM-RR perils. Whereas CD18 receptor neutralization, undermines both $\mathrm{CML}$ adhesion and migration, is shown to be instrumental in this study. ( ${ }^{*} \mathrm{p} \leq 0.05$ ). (b)The binding of NFKB to IL7 is not affected by IR exposure or/and LiCltreatment. Whereas NFKB binding to IL8 was decreased in the presence of LiCl and Li10Gy. The MMP1 promoter binding to NFKB was enhanced at Li10Gy treatment.

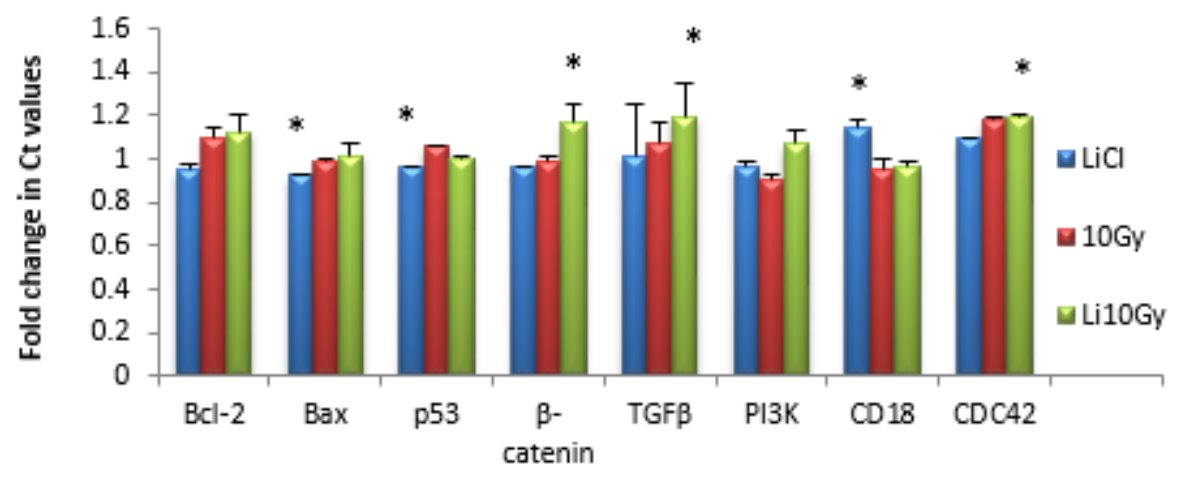

Genes

(a)

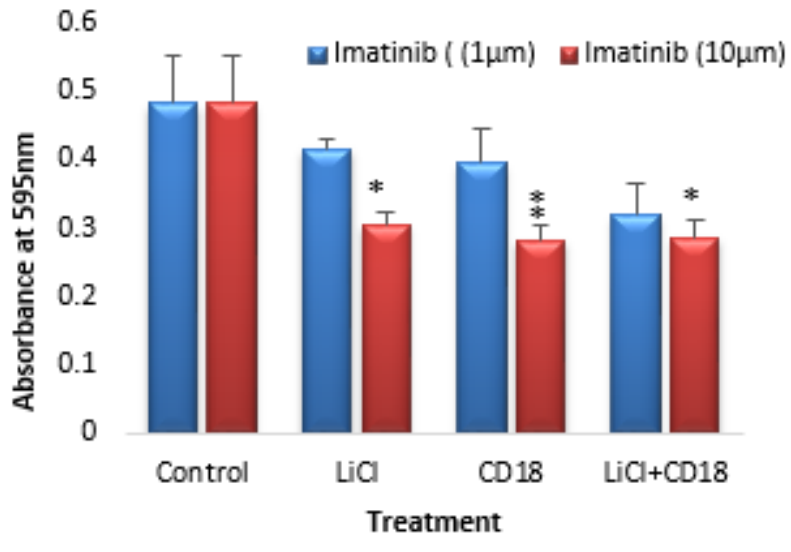

(b)

\section{Figure 11}

(a) The non-canonical pathway metastasizes cancer, whereas Wnt/ $\beta$-catenin signaling (a target of GSK3 $\beta$ ) is directly associated with colorectal, gastric, hepatocellular, ovarian, breast and prostate cancers. $\mathrm{PI} 3-\mathrm{Rac1} / \mathrm{RhoA} / \mathrm{CDC} 42$ signaling, which is vital in cell migration, is activated through TGF $\beta$ and CD18 both. GSK3 $\beta$ inhibition with IR exposure transcribes more of TGF $\beta, P I 3 K$, and CDC42 in addition to $\beta$ catenin. TGF $\beta$ distinctively as a cytokine, is known to bestow antitumor immunity(34). The CD18 RNA, specifically, upregulated only on $\mathrm{LiCl}$ exposure but its significant protein appearance on combination with radiation likely indicates involvement of other factors or hyperactivated transcription factors. ( $\left.{ }^{\star} p \leq 0.05\right)$. 


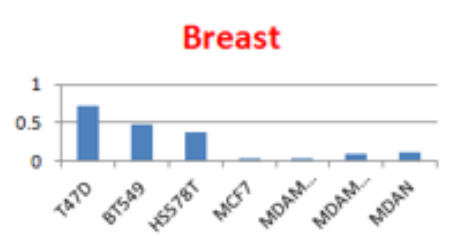

Ovarian

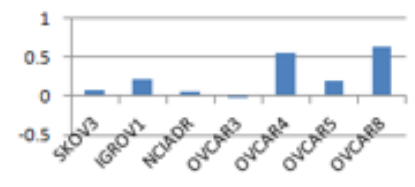

Leukemia

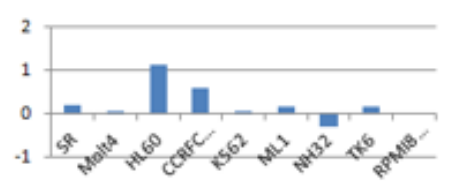

CNS

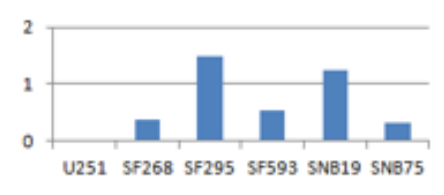

Colon

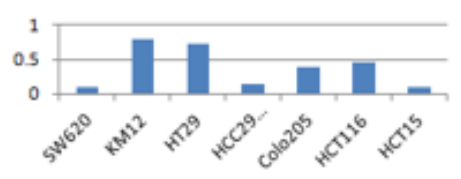

Renal

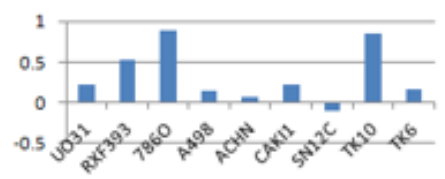

Lungs

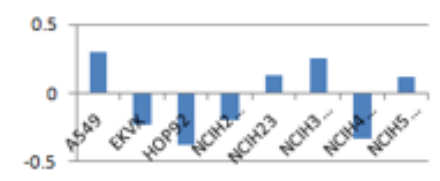

Melanoma

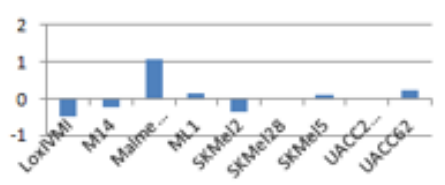

Prostate

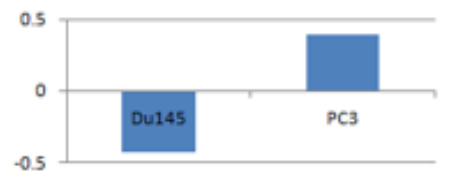

(a)

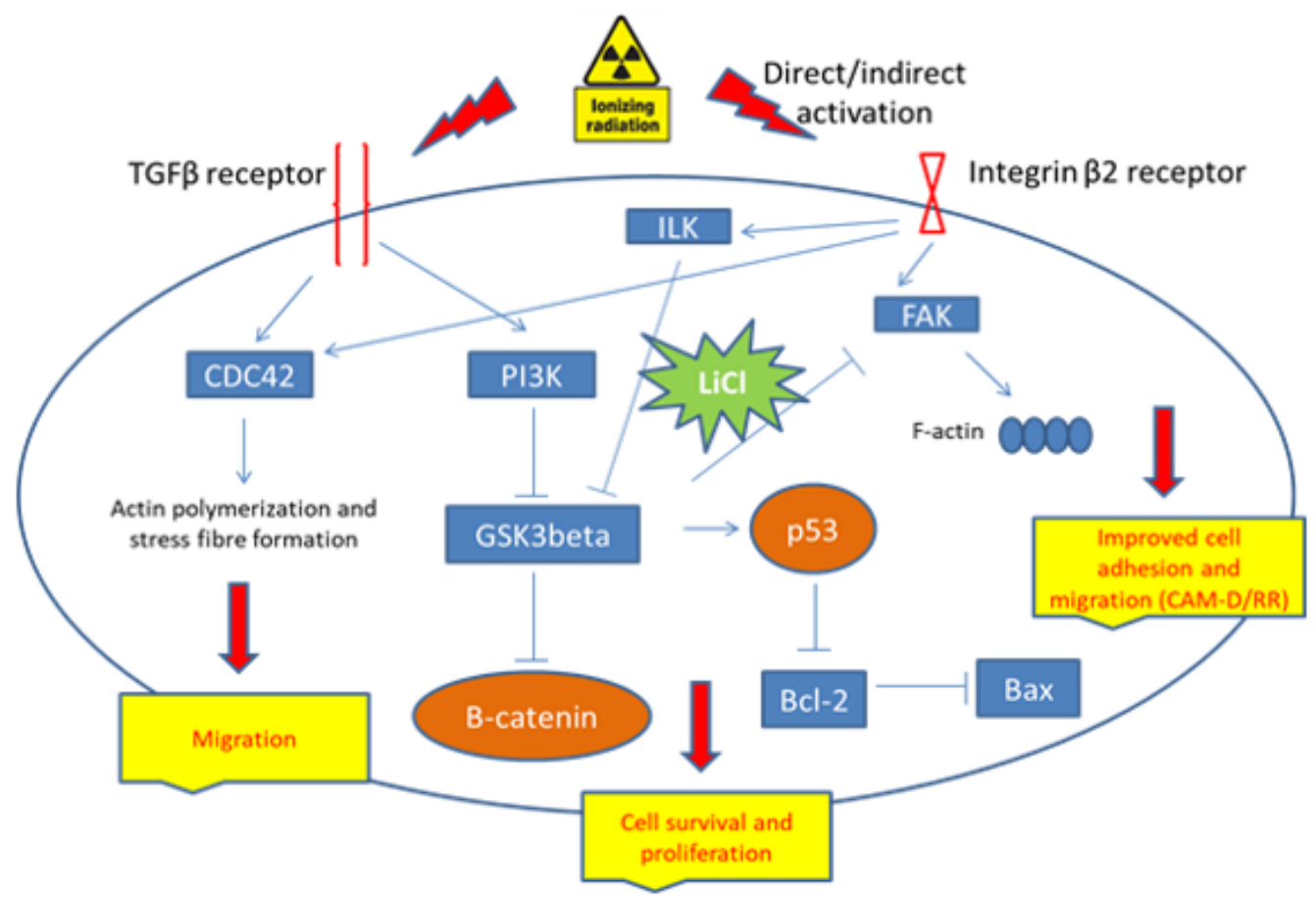

(b)

\section{Figure 12}

(a)Tissue-based classification of $\mathrm{NCl} 60$ microarray data revealed consistent over-representation of CD18 across CNS (central nervous system), ovarian, breast and colon cancers. In almost all leukemia and renal cancers, CD18 transcription was more whereas it was in opposition in lung cancer and melanoma, suggesting CD18 differential prognostic and diagnostic importance in various cancers. (b) Mechanistic basis of $\beta 2$ integrin mediated CAM-D/RR. 


\section{Supplementary Files}

This is a list of supplementary files associated with this preprint. Click to download.

- Supplementaryfile.docx 